\title{
Gas phase formation of extremely oxidized pinene reaction products in chamber and ambient air
}

\author{
M. Ehn ${ }^{1}$, E. Kleist ${ }^{2}$, H. Junninen ${ }^{3}$, T. Petäjä ${ }^{3}$, G. Lönn ${ }^{3}$, S. Schobesberger ${ }^{3}$, M. Dal Maso ${ }^{3}$, A. Trimborn ${ }^{1,4}$, \\ M. Kulmala ${ }^{3}$, D. R. Worsnop ${ }^{3,5}$, A. Wahner ${ }^{1}$, J. Wildt ${ }^{2}$, and Th. F. Mentel ${ }^{1}$ \\ ${ }^{1}$ Institute for Energy and Climate Research (IEK-8), Forschungszentrum Jülich, 52425 Jülich, Germany \\ ${ }^{2}$ Institute of Bio- and Geosciences (IBG-2), Forschungszentrum Jülich, 52425 Jülich, Germany \\ ${ }^{3}$ Department of Physics, P.O. Box 64, 00014 University of Helsinki, Finland \\ ${ }^{4}$ Aeromegt $\mathrm{GmbH}$, Verbindungsstraße 27, 40723 Hilden, Germany \\ ${ }^{5}$ Aerodyne Research, Inc., 45 Manning Road, Billerica, MA 01821, USA
}

Correspondence to: M. Ehn (m.ehn@fz-juelich.de)

Received: 25 January 2012 - Published in Atmos. Chem. Phys. Discuss.: 8 February 2012

Revised: 25 May 2012 - Accepted: 27 May 2012 - Published: 11 June 2012

\begin{abstract}
High molecular weight (300-650 Da) naturally charged negative ions have previously been observed at a boreal forest site in Hyytiälä, Finland. The long-term measurements conducted in this work showed that these ions are observed practically every night between spring and autumn in Hyytiälä. The ambient mass spectral patterns could be reproduced in striking detail during additional measurements of $\alpha$-pinene $\left(\mathrm{C}_{10} \mathrm{H}_{16}\right)$ oxidation at low-OH conditions in the Jülich Plant Atmosphere Chamber (JPAC). The ions were identified as clusters of the nitrate ion $\left(\mathrm{NO}_{3}^{-}\right)$and $\alpha$ pinene oxidation products reaching oxygen to carbon ratios of $0.7-1.3$, while retaining most of the initial ten carbon atoms. Attributing the ions to clusters instead of single molecules was based on additional observations of the same extremely oxidized organics in clusters with $\mathrm{HSO}_{4}^{-}$ (Hyytiälä) and $\mathrm{C}_{3} \mathrm{~F}_{5} \mathrm{O}_{2}^{-}$(JPAC). The most abundant products in the ion spectra were identified as $\mathrm{C}_{10} \mathrm{H}_{14} \mathrm{O}_{7}, \mathrm{C}_{10} \mathrm{H}_{14} \mathrm{O}_{9}$, $\mathrm{C}_{10} \mathrm{H}_{16} \mathrm{O}_{9}$, and $\mathrm{C}_{10} \mathrm{H}_{14} \mathrm{O}_{11}$. The mechanism responsible for forming these molecules is still not clear, but the initial reaction is most likely ozone attack at the double bond, as the ions are mainly observed under dark conditions. $\beta$-pinene also formed highly oxidized products under the same conditions, but less efficiently, and mainly $\mathrm{C}_{9}$ compounds which were not observed in Hyytiälä, where $\beta$-pinene on average is 4-5 times less abundant than $\alpha$-pinene. Further, to explain the high $\mathrm{O} / \mathrm{C}$ together with the relatively high $\mathrm{H} / \mathrm{C}$, we propose that geminal diols and/or hydroperoxide groups may be important. We estimate that the night-time concentration of
\end{abstract}

the sum of the neutral extremely oxidized products is on the order of $0.1-1 \mathrm{ppt}\left(\sim 10^{6}-10^{7} \mathrm{molec} \mathrm{cm}^{-3}\right)$. This is in a similar range as the amount of gaseous $\mathrm{H}_{2} \mathrm{SO}_{4}$ in Hyytiälä during day-time. As these highly oxidized organics are roughly 3 times heavier, likely with extremely low vapor pressures, their role in the initial steps of new aerosol particle formation and growth may be important and needs to be explored in more detail in the future.

\section{Introduction}

Earth's atmosphere contains a large variety of different trace gases, produced both from biogenic and anthropogenic sources. Many of these trace gases impact everyday life, either through their influence on air quality (e.g. $\mathrm{SO}_{2}$, tropospheric ozone, $\mathrm{NO}_{\mathrm{x}}$ ) or climate. The climate-influence occurs both through the greenhouse effect from e.g. $\mathrm{CO}_{2}$ and $\mathrm{CH}_{4}$, as well as through oxidation products of trace gases that can condense onto, or even form new, aerosol particles. These aerosol particles can either directly scatter incoming solar radiation, or form cloud droplets that affect radiative transfer even more efficiently. The most important inorganic precursors for aerosol formation are $\mathrm{SO}_{2}, \mathrm{NO}_{\mathrm{x}}$, and $\mathrm{NH}_{3}$, but often the organic mass fraction of sub-micron aerosol is significant or even dominant (Kanakidou et al., 2005; Zhang et al., 2007). Organic aerosol (OA) can be primary, i.e. emitted directly as aerosol particles, or secondary, formed from 
a wide range of different organic trace gases. The organic trace gases are typically referred to as volatile organic compounds (VOCs), which upon oxidation form products with low enough vapor pressure to form OA. It has been estimated that $10^{4}-10^{5}$ different atmospheric organic species have been measured, and especially biogenic terpenoids have been reported as important players in gas-phase and particulatephase chemistry (Goldstein and Galbally, 2007).

VOCs in the atmosphere are oxidized by reactions with ozone, $\mathrm{OH}$ and $\mathrm{NO}_{3}$ radicals. During daytime, $\mathrm{OH}$ is the most important oxidant, but it has been reported that the sum of all identified inorganic trace gases and VOCs cannot explain the observed OH reactivity (Di Carlo et al., 2004), implying that there exists groups of compounds that are yet to be identified. Holzinger et al. (2005) suggested that highly reactive biogenic precursors could at least partially explain the missing reactivity. Nevertheless, clear discrepancies still exist between models and experiments on secondary organic aerosol (SOA) formation from known organic precursors (Hallquist et al., 2009; Kroll and Seinfeld, 2008).

The mechanism of how organic molecules take part in the first steps of nucleation and growth of new particles has been the focus of several studies in recent years (Paasonen et al., 2010; Metzger et al., 2010), but no conclusive results have yet been obtained. It is widely agreed that sulfuric acid plays an important role in the initial formation step (Weber et al., 1996; Petäjä et al., 2009; Riipinen et al., 2007) whereas other compounds, most likely organics, are needed to explain the majority of the early growth (Kulmala et al., 2001; Ehn et al., 2007; Wehner et al., 2005). Some studies have shown that sulfuric acid alone could explain observed atmospheric formation rates (Sipilä et al., 2010), others that also ammonia or amines are needed (Kirkby et al., 2011; Berndt et al., 2010), and yet others that organics are important (Metzger et al., 2010). Due to high ion concentrations, Kirkby et al. (2011) could directly measure the nucleating clusters of $\mathrm{H}_{2} \mathrm{SO}_{4}$ and $\mathrm{NH}_{3}$, while Wang et al. (2010) suggested three different mechanisms where specific organic precursor molecules were involved in nucleation and growth up to 20 $\mathrm{nm}$. Nevertheless, a conclusive determination of which organics can take part in the first steps of atmospheric new particle formation (NPF) is still incomplete, both related to the chemical mechanism and the specific organic molecules involved.

The formation of new particles can also be enhanced by ions. An additional positive or negative charge can stabilize clusters, slowing their re-evaporation, and thereby facilitating the initial growth. Frequent NPF events have been reported to take place in the boreal forest site in Hyytiälä, Finland (Dal Maso et al., 2005), and most studies on the role of ions in NPF have found that only around $10 \%$ or less of new particles are typically formed through ion-enhancement (Gagne et al., 2008; Kulmala et al., 2010). However, others have found ions to play a dominant role in NPF at the same site (e.g. Yu and Turco, 2011).
Naturally charged ions are formed through high-energy collisions of air molecules with energetic particles, mainly from galactic cosmic rays or the radio-active decay of radon (Laakso et al., 2004; Arnold, 2008; Harrison and Carslaw, 2003). The initially formed primary ions are mainly positively and negatively charged $\mathrm{N}_{2}$ and $\mathrm{O}_{2}$, but as these ions quickly collide with stronger acids (negative ions) or bases (positive ions), charge transfer and/or clustering will occur. Typical long-lived negative ions comprise $\mathrm{NO}_{3}^{-}, \mathrm{HSO}_{4}^{-}$, strong organic acids, and their clusters (e.g. Eisele, 1989b; Ehn et al., 2010). In the positive ion spectrum, the dominant peaks are typically alkyl pyridines and alkyl amines (e.g. Ehn et al., 2010; Eisele, 1989a). Typical naturally charged ion concentrations are around $100-1000 \mathrm{~cm}^{-3}$ per polarity, but due to the complex and dynamic process forming these ions, the concentration of a certain ion can rarely be translated to a real concentration of the corresponding neutral molecule.

The aim of this work was to explore in more detail the group of high molecular weight ions (mass range roughly 300-650 Da) recently detected by Ehn et al. (2010) in Hyytiälä. These ions typically dominated the night-time negative ion spectra together with nitric acid. At that time, the authors did not have enough information available to identify these peaks, but speculated that the elemental composition suggested highly oxidized, nitrogen-containing organics. If correct, this would suggest a new, to our knowledge not previously identified group of compounds, which might contribute significantly to organic aerosol and new aerosol particle formation.

In this paper, new long-term measurements in Hyytiälä together with extensive measurements at the Jülich Plant Atmosphere Chamber (JPAC) in Jülich, Germany, are combined to provide a conclusive elemental composition for the high-mass ion species initially observed by Ehn et al. (2010). Their suggestions on the composition was confirmed, but as this group of molecules has never been observed or identified before, the emphasis of this paper is to describe the different methods used to unambiguously determine the elemental composition. Additionally, we give a lower limit estimate on the abundance of the highly-oxidized organic ions, and shortly discuss their importance and possible formation mechanisms in the atmosphere.

\section{Methods}

\section{$2.1 \quad$ APi-TOF}

The chemical characterization of the ion population was performed with the Atmospheric Pressure interface Time-OfFlight mass spectrometer (APi-TOF, Aerodyne Research Inc. \& Tofwerk AG; Junninen et al., 2010). It consists of a short APi which samples roughly $0.81 \mathrm{~min}^{-1}$ through a critical orifice, and consequently guides the sampled ions towards the mass spectrometer while pumping away the gas in 3 stages. 
In other words, no ionization is performed, and the instrument relies on the sampled air containing naturally charged ions. Once the ions reach the TOF they are orthogonally extracted onto a one- or three-reflection flight path, and the mass of the ions are determined based on their flight times. In this work, two APi-TOFs were used, and they will forthwith be titled the "Jülich" and the "Helsinki" APi-TOFs, respectively. As the unit for mass, we use Dalton (Da), and as the unit for mass-to-charge we will use Thomson (Th), which corresponds to Da per elementary charge. When discussing peaks at only unit mass-to-charge resolution (UMR), we will use e.g. "UMR $62 \mathrm{Th}$ " to denote the location of $\mathrm{NO}_{3}^{-}$(exact mass-to-charge $61.9884 \mathrm{Th}$ ). Additionally, we assume that all the detected ions are singly charged, as none of our results suggest otherwise. Only negative ions are discussed in this study, as this is the polarity where the highly oxidized ions were observed.

The mass accuracy of the APi-TOF is specified by the manufacturer as $20 \mathrm{ppm}(0.002 \%)$, although the instrument can typically be calibrated to less than $10 \mathrm{ppm}$. The typical achievable resolution is around $4000 \mathrm{Th} / \mathrm{Th}$ (ranges from 3000-5000 depending on the exact tuning) when operating in normal, single reflection mode ("V mode"). Two additional reflections inside the TOF can be used, thus producing a flight path in the shape of a W ("W mode") to increase the resolution. However, the increased resolution is accompanied by a significant decrease in sensitivity, and thus requires longer averaging times to achieve the same signal-to-noise as in V mode. Only the Jülich APi-TOF was operated in W mode, and the resolution reached slightly above $8000 \mathrm{Th} / \mathrm{Th}$ in the region of 200-700 Th. The typical transmission of the APi-TOF in V mode is on the order of $0.1-1 \%$ in the massto-charge range of 50-800 Th (Junninen et al., 2010), which was of interest in this study.

Evaporation and fragmentation may occur to some extent inside the instrument. Particularly water, which is believed to be clustered with most of the ions at ambient conditions, is typically weakly bound and evaporates from the ions before reaching the TOF region. More strongly bound clusters may also fragment inside the APi-TOF, but based on previous measurements with the instrument, clusters have been frequently detected at high concentrations, suggesting that fragmentation is not a critical issue (Junninen et al., 2010). Additionally, two low-resolution ion mobility spectrometers measuring at ambient pressures were recently found to agree within measurement accuracies with the ion distribution of the APi-TOF, further suggesting that the measured ions are not purely fragments of much larger ion clusters (Ehn et al., 2011).

\subsection{Measurements}

The ambient measurements were performed during MayNovember 2010 at the SMEAR II station in Hyytiälä, Finland (Hari and Kulmala, 2005). The site is located within the boreal forest, with the site being mainly surrounded by Scots pine (Pinus Sylvestris L.). The ion measurements were performed using the Helsinki APi-TOF.

The chamber measurements were performed at the Jülich plant atmosphere chamber facility (JPAC; Mentel et al., 2009) at Forschungszentrum Jülich, Germany. The facility consists of three Borosilicate glass chambers (1641, 11501, and 14501) with Teflon floors, but only the 14501 chamber was used in this work. This reaction chamber is mounted in a climate controlled housing, and has the capability of using both real plant emissions from the other chambers, and pure compounds from diffusion sources for further oxidation reactions. For these measurements only pure $\alpha$ - or $\beta$-pinene was used, at concentration ranging from a few ppb to several tens of ppb. In addition to the VOCs, ozone and water vapor were constantly added to the chamber via separate inlets. The conditions used in the reported measurements were $T=16 \pm 1^{\circ} \mathrm{C}, \mathrm{RH}=63 \pm 3 \%$, and $\mathrm{O}_{3}$ around $85 \mathrm{ppb}$ depending on the amount of added organics. These conditions were similar to the ones used by Mentel et al. (2009), who showed that particle formation events similar to those observed in the boreal forest could be attained in JPAC. VOC concentrations were measured at the inlet and the outlet air of the reaction chamber using a GC-MS (Heiden et al., 1999). The chamber is operated at a constant flow mode with in- and outflow kept constant at around $301 \mathrm{~min}^{-1}$, giving an average residence time in the chamber of roughly $50 \mathrm{~min}$. The system can be kept in steady state for long periods of time, facilitating longer averages with the APi-TOF which are specifically needed for $\mathrm{W}$ mode measurements. These ion measurements were performed with the Jülich APi-TOF. All measurements were performed under low $\mathrm{NO}_{\mathrm{x}}$ conditions $\left(\mathrm{NO}_{\mathrm{x}}<300 \mathrm{ppt}\right)$, and in the absence of UV light.

\subsection{Data analysis and APi-TOF mass calibration}

All the data presented in this work are from naturally charged ions, therefore these mass spectra require very different interpretation than more commonly presented spectra from instruments using active ionization methods. The main reason is that in the latter instruments, the ionization is directly followed by detection, optimally resulting in a more or less linear response from neutral concentrations to detected ions. For naturally charged ions, detection often occurs several minutes after ionization, which means that the charge can be transferred countless times before detection, and therefore the process will be extremely selective, but at the same time sensitive, to molecules with high (positive ions) and low (negative ions) proton affinities. Additionally, the total ion concentration is in practice controlled by physical processes and is not affected by the molecular composition of trace gases in the air.

The APi-TOF data was analyzed using the MatLabbased tofTools package originally described by Junninen et 


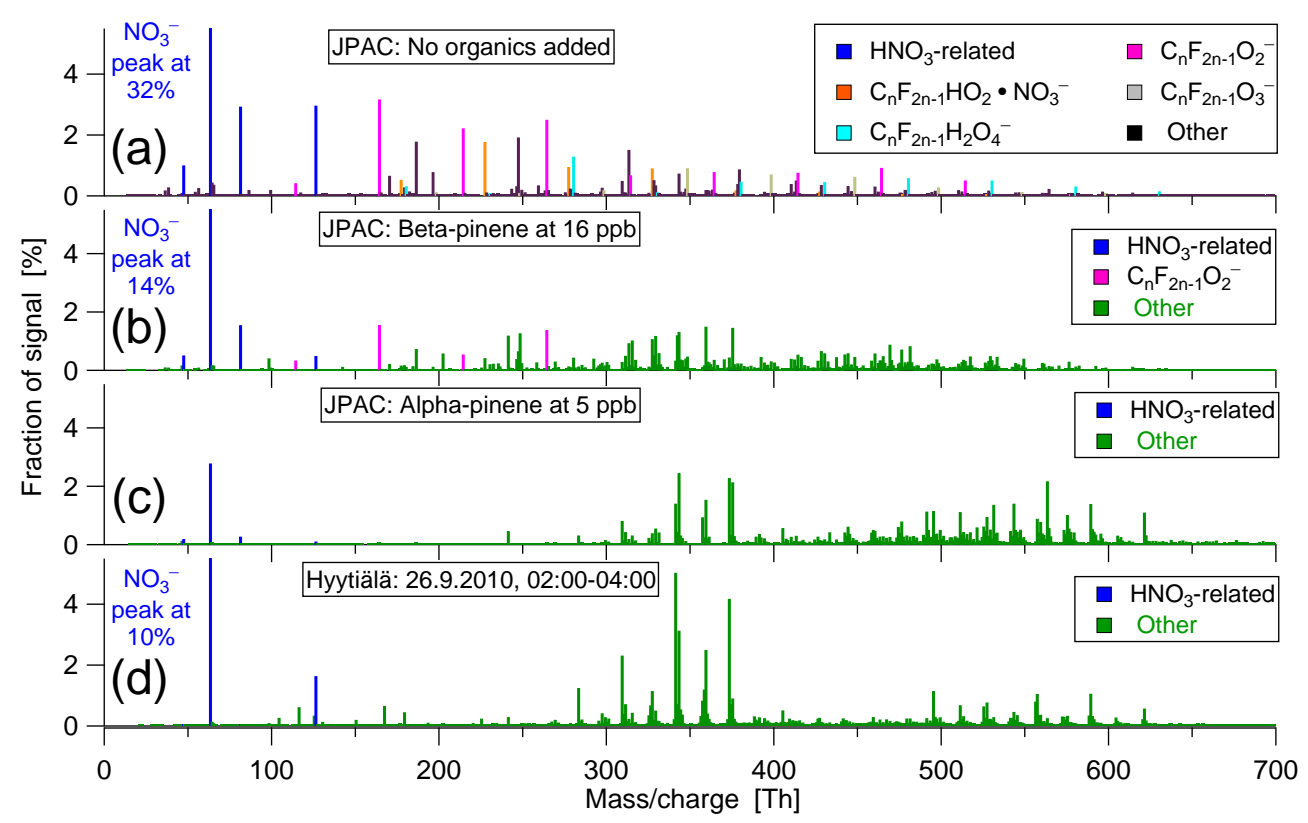

Fig. 1. Negative ion spectra from the JPAC at three different chamber conditions ((a): no addition, (b): $\beta$-pinene added, (c): $\alpha$-pinene added) and from Hyytiälä (d). The $\mathrm{NO}_{3}^{-}$signal is allowed to go off scale in (a), (b), and (d). In these cases the peak values are written out explicitly.

al. (2010), though the toolbox has since been extensively improved and expanded.

With the high accuracy and resolution of the APi-TOF, the possible elemental composition of a peak can be narrowed down significantly compared to unit mass-to-charge resolution (UMR) data. However, for this purpose it is extremely important to have a good conversion from time-of-flight to mass/charge (typically referred to as the "mass calibration"). For the APi-TOF, the typical 2-parameter mass calibration (Junninen et al., 2010)

$\frac{m}{Q}=\left(\frac{t-b}{a}\right)^{n}, n=2$,

where $m / Q$ is mass/charge, $t$ is time-of-flight, and $a$ and $b$ are the free parameters, could not provide the desired high accuracy over the entire 50-700 Th region of interest. Allowing the exponent $n$ in Eq. (1) to vary, greatly improved the fit over the desired range. This method with a variable exponent has been used previously in other instruments, for example in the Aerodyne aerosol mass spectrometer (AMS), which uses the same TOF mass spectrometer (DeCarlo et al., 2006).

The mass calibration is usually performed by using known ions in the spectrum for the calibration, and optimally these peaks should span the entire range to be calibrated. The APiTOF does not have any "background" signals that are independent of the sample, and therefore the peaks used for calibration vary with the sampled air, which means that other methods need to be employed for the mass calibration. In this work, the starting point was a mass spectrum where known peaks only existed in the sub $200 \mathrm{Th}$ range, and the main range of interest was in the 300-600 Th range. This meant that peak identification was initially made in the lowest mass/charge region where the calibration was the most reliable based on previously identified peaks, such as $\mathrm{NO}_{3}^{-}$, $\mathrm{HNO}_{3} \cdot \mathrm{NO}_{3}^{-}, \mathrm{C}_{3} \mathrm{~F}_{5} \mathrm{O}_{2}^{-}$. The original calibration was used to preliminarily identify additional peaks in the $200-300 \mathrm{Th}$ range, and once successful, the new peaks were used to improve the calibration. This step-wise identification allowed the entire mass range of interest to be covered. With the final 3-parameter fit acquired through this iterative method, all identified ions were well within the $20 \mathrm{ppm}$ instrumental accuracy.

\section{Results}

\subsection{Comparison of negative ion spectra from Hyytiälä and the JPAC}

High molecular weight ions have previously been reported from Hyytiälä (Ehn et al., 2010), and now additional longterm measurements during May-November 2010 showed that these ions are indeed abundant almost every night. However, with frequently changing ambient conditions, the conclusive elemental identification of the ions proved a difficult task. For this reason, we tried to mimic the spectra under controlled chamber conditions at the JPAC.

To fully characterize the ion spectra in the JPAC, first the background chamber spectra were studied. Some level of contamination is inevitable in all chambers, and when only $\mathrm{H}_{2} \mathrm{O}$ and $\mathrm{O}_{3}$ are added to the cleaned air going into the chamber, the negative ion spectrum is dominated by the most 


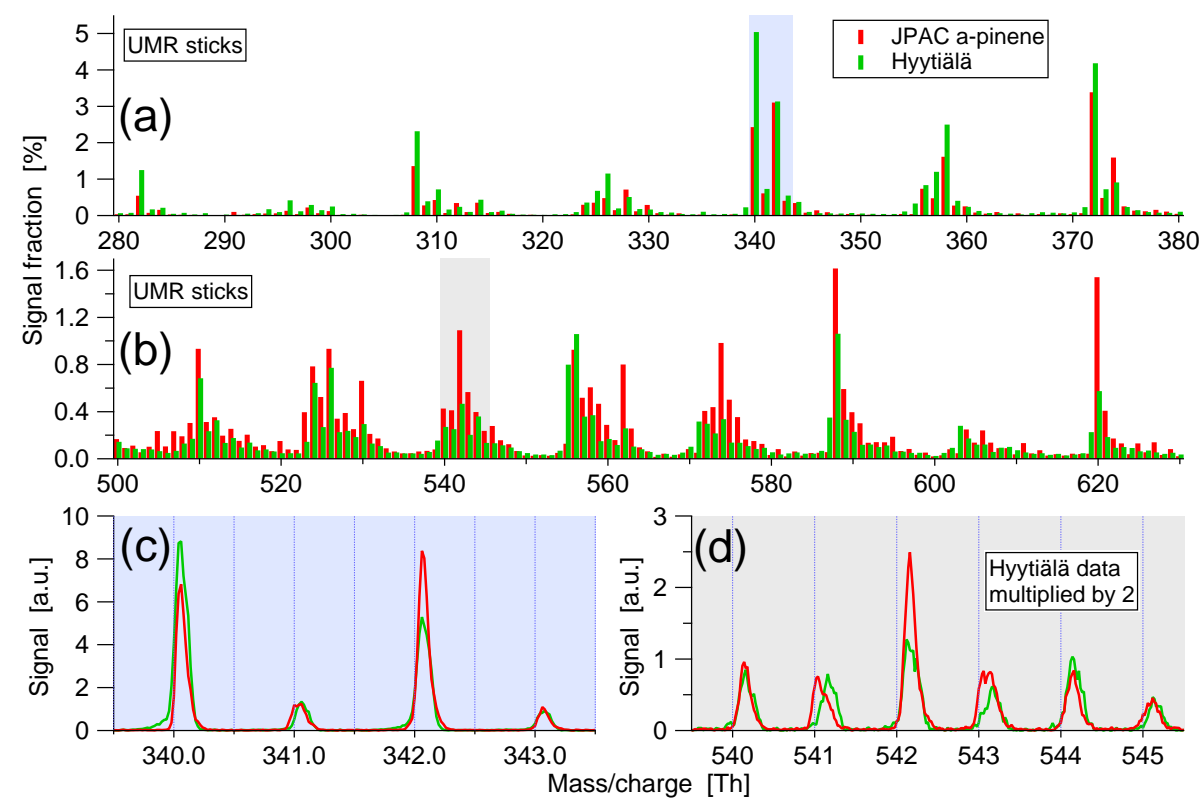

Fig. 2. UMR (a and $\mathbf{b}$ ) and high-resolution (c and $\mathbf{d}$ ) comparison of JPAC a-pinene (red) and Hyytiälä ambient (green) data. The bars have been offset slightly for an easier comparison. The spectra correspond to Fig. 1c and d, respectively. The blue-shaded region in plot (a) corresponds to (c), and the grey-shaded region in (b) corresponds to (d).

acidic contaminants. The dominant peak in this case is nitric acid, $\mathrm{NO}_{3}^{-}$, at UMR $62 \mathrm{Th}$, as shown in Fig. 1a. The $\mathrm{NO}_{3}^{-}$signal is allowed to go off-scale to better show the rest of the spectrum. $\mathrm{NO}_{3}^{-}$is one of the most common negative ions also in the atmosphere, and due to its "stickiness" it is extremely hard to remove completely once introduced into a chamber. In the chamber, previous experiments with $\mathrm{NO}_{\mathrm{x}}$ and $\mathrm{OH}$ have produced $\mathrm{HNO}_{3}$ which only very slowly desorbs from the walls. The rest of the ion signal is distributed over the entire spectrum, and is mostly explained by perfluorinated organic acids. The most abundant perfluorinated ion is typically $\mathrm{C}_{3} \mathrm{~F}_{5} \mathrm{O}_{2}^{-}$at UMR $163 \mathrm{Th}$. The unit mass of a $\mathrm{CF}_{2}$ group is 50 , and the homologous series is clearly visible at peaks 113, 163, 213, 263, etc. up to at least $563 \mathrm{Th}$. Several of these acids, mainly the $\mathrm{C}_{8}$ perfluorooctanoic acid at $(413 \mathrm{Th})$ is used as a surfactant in the emulsion polymerization of fluoropolymers, such as Teflon. Much of the tubing, as well as the bottom plate of the chamber is made of Teflon, and thus the presence of these molecules is not surprising, and likely a common contaminant in many chambers. However, efforts have been made to exchange as much as possible of the Teflon tubing for steel or glass equivalents.

The fluorinated acids are weaker acids than $\mathrm{HNO}_{3}$, and thus if the $\mathrm{HNO}_{3}$ concentration in the chamber is increased, the ion signal from the fluorinated acids decreases, although the concentration of neutral fluorinated acids remain unchanged. Similarly, when adding organics to the chamber, the amount of neutral fluorinated compounds should not decrease, but their influence on the ion spectrum diminishes, mainly due to stronger acids forming from the oxidation products of the organics (Fig. 1b-c). Figure $1 \mathrm{~b}$ shows the negative ion spectrum measured in the chamber with a $\beta$ pinene concentration of $16 \mathrm{ppb} . \mathrm{NO}_{3}^{-}$is still the largest peak, but several new peaks have appeared while many fluorinated ions have disappeared. The most clearly distinguishable fluorinated compounds are the $\mathrm{C}_{3}-\mathrm{C}_{5}$ acids at UMR 113,163 , and 213.

Figure 1c shows the resulting spectrum with $5 \mathrm{ppb} \alpha$ pinene in the chamber. Although using clearly lower organic precursor concentrations than in the aforementioned $\beta$-pinene experiment, many more highly acidic organic products seem to have formed, as $\mathrm{NO}_{3}^{-}$has decreased dramatically and the fluorinated compounds are barely detectable. A clear pattern of peaks has formed in the 300-400 Th range, and a second pattern is visible at 500-650 Th.

Figure 1d shows a typical night-time negative ion spectrum acquired in Hyytiälä. The similarity to the JPAC $\alpha$ pinene spectrum in Fig. 1c is striking. The nitric acid dimer $\left(\mathrm{HNO}_{3} \cdot \mathrm{NO}_{3}^{-}\right)$at UMR $125 \mathrm{Th}$ is much larger in Hyytiälä, reflecting that the total amount of neutral $\mathrm{HNO}_{3}$ is higher, but the same modes in the 300-400 and 500-650 Th ranges are visible in both Hyytialä and JPAC. The day-time negative ion spectra look very different compared to the night-time spectra in Hyytiälä, with days often dominated by $\mathrm{H}_{2} \mathrm{SO}_{4}$-related ions, but also the amount of different organics are most likely higher due to the increased amount of $\mathrm{OH}$. All-in-all, the appearance of $\mathrm{H}_{2} \mathrm{SO}_{4}$ makes the amount of negative charges available for the organics lower, and the increased amount of different organics spreads out the signal over many more ions. Therefore the ions observed at night cannot be clearly 
identified during day. This does not, however, necessarily mean that the corresponding neutral molecules would not exist in the gas-phase during day-time, it only means that we cannot detect them with as high sensitivity as during nighttime.

The good agreement between the JPAC $\alpha$-pinene and the Hyytiälä ion spectra suggest that the ions are similar, and the identification can be done based on JPAC data. $\alpha$-pinene is one of the most abundant monoterpenes in Hyytiälä, typically 4-5 times more abundant than $\beta$-pinene (Hakola et al., 2003 ), and based on the comparison between $\alpha$-pinene and $\beta$-pinene in JPAC it seems to be especially efficient at producing molecules prone to form negative cluster ions. To make sure that the detected ions are the same, a more detailed plot of the internal patterns of the modes in Fig. 1c and $\mathrm{d}$ is presented in Fig. 2a and b. Both plots show unit massto-charge resolution data, and the spectral patterns agree extremely well, especially in the $300-400 \mathrm{Th}$ region. Above $400 \mathrm{Th}$, both in Figs. 1 and 2, one can make out some differences, but the majority of the UMR patterns are largely consistent. Figure $2 \mathrm{c}$ and d depict some major peaks (UMR 340 and 342 Th in Fig. 2c, and 540 and 542 in Fig. 2d) in high resolution to show that also at a resolution of 3000-4000 these ions are the same in both spectra. There are peaks, like UMR 341, 541 and 543, that contain species that are visible in JPAC but not in Hyytiälä, and this will be discussed in more detail in the following sections. However, we conclude that the $\alpha$-pinene negative ion spectrum in JPAC is largely representative of the typical night-time ions observed in Hyytiälä.

\subsection{Identification of the elemental composition}

To make a conclusive elemental identification of the $\alpha$ pinene produced peaks using the maximum resolution of the instrument, the chamber was set to operate in steady state over one night, and the APi-TOF was tuned to $\mathrm{W}$ mode with a resolution above 8000 for peaks above $300 \mathrm{Th}$. A $6 \mathrm{~h}$ average was acquired to achieve good signal-to-noise, and 16 of the largest and "cleanest" peaks were used to calibrate the mass axis. By "clean", we refer to the peaks which had the lowest full widths at half maximum (FWHM), in contrast to broader peaks that most likely contained several overlapping ions and were thus discarded. Gaussian peaks were fit to the 16 ions, and the mass axis was fit onto the time-of-flight axis using the 3-parameter fit described previously. The errors between the fitted Gaussians and the 3-parameter fit are plotted in Fig. 3. The dashed grey lines depict $\pm 10 \mathrm{ppm}$ accuracy, and clearly all proposed ions are within this range. As an example, we will take a closer look at UMR $340 \mathrm{Th}$, which was used for the calibration. At this mass/charge, $10 \mathrm{ppm}$ corresponds to $0.0034 \mathrm{Th}$, and the proposed ion is $\mathrm{C}_{10} \mathrm{H}_{14} \mathrm{NO}_{12}$ with a mass of 340.0521 . Within the range $340.0521 \pm 0.0034$ $\mathrm{Th}$, there are only 18 different ions comprised of $\mathrm{C}, \mathrm{H}, \mathrm{N}$ and $\mathrm{O}$. However, out of these 18 ions, most can be discarded

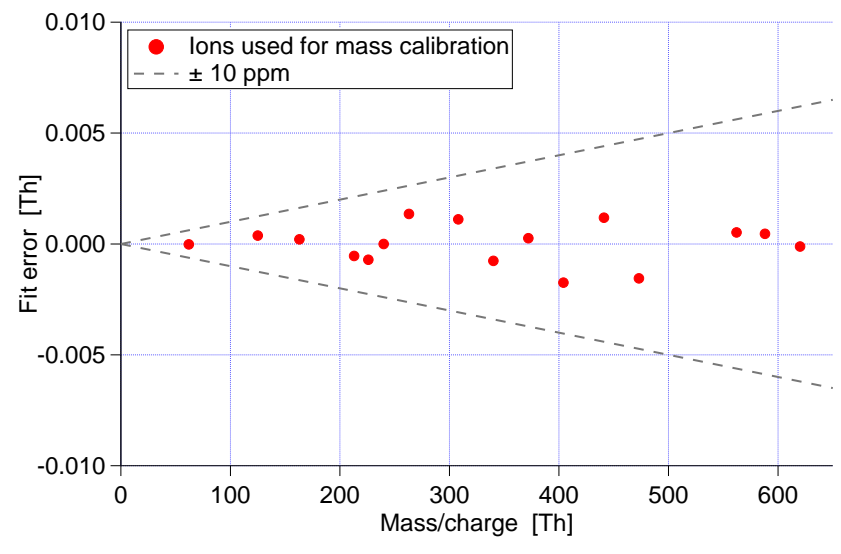

Fig. 3. Fit errors of the ions used for mass axis calibration. Gaussian fits were made to 16 peaks in the $\mathrm{W}$-mode ion spectrum from JPAC. These peaks were attributed to specific elemental compositions and used for mass calibration. The selected peaks contained nitric acid, fluorinated acids, and organics to span the entire mass range of interest. The resulting errors between the fit masses and the assumed elemental compositions (red dots) where all well within $\pm 10 \mathrm{ppm}$ accuracy (grey dashed lines), strongly suggesting that all chosen peaks were correctly identified.

as unreasonable based on their elemental compositions: 13 of the molecules have double bond equivalents higher than 8 , and of the remaining 5 , two have more than 3 nitrogen atoms. Discarding all the aforementioned ions, the remaining ions are $\mathrm{C}_{10} \mathrm{H}_{14} \mathrm{NO}_{12}^{-}, \mathrm{C}_{7} \mathrm{H}_{16} \mathrm{O}_{15}^{-}, \mathrm{H}_{20} \mathrm{O}_{20}^{-}$. The last two have unreasonably high amounts of oxygen, and additionally defy the "nitrogen rule" which states that a deprotonated ion at an even mass should contain an odd number of nitrogen atoms. Thus we are left with only the suggested $\mathrm{C}_{10} \mathrm{H}_{14} \mathrm{NO}_{12}^{-}$ion. As the precursor in the experiment was $\mathrm{C}_{10} \mathrm{H}_{16}$, the identification seems appropriate.

As yet another approach to test the elemental composition, one can look at the isotopic distributions of the ions. Keeping UMR $340 \mathrm{Th}$ as an example, Fig. 4 shows data from Hyytiälä together with both $\mathrm{V}$ and $\mathrm{W}$ mode data from JPAC. In the left-hand graph (Fig. 4a), Gaussian fits were made to the three data sets. The peaks are scaled to not overlap, and thus the signal is in arbitrary units. However, the difference in peak resolution is still real, and one can see that the JPAC APi-TOF was tuned to a slightly higher resolution (i.e. lower FWHM) than the one in Hyytiälä in V mode. The JPAC $\mathrm{W}$ mode resolution was still almost twice that of the JPAC V mode. The Gaussian fits provide peak areas corresponding to ion concentrations. Assuming that the ion signals at UMR $340 \mathrm{Th}$ are purely from $\mathrm{C}_{10} \mathrm{H}_{14} \mathrm{NO}_{12}^{-}$, one can calculate how much of the signal at UMR $341 \mathrm{Th}$ is due to the isotopes of this ion. The measured spectra at UMR 341 Th (solid lines), together with the calculated isotopes from UMR $340 \mathrm{Th}$ (dashed lines) are plotted in Fig. 4b. In Hyytiälä almost all of UMR 341 Th is explained by the isotope, and as there is some signal at almost every integer mass, 


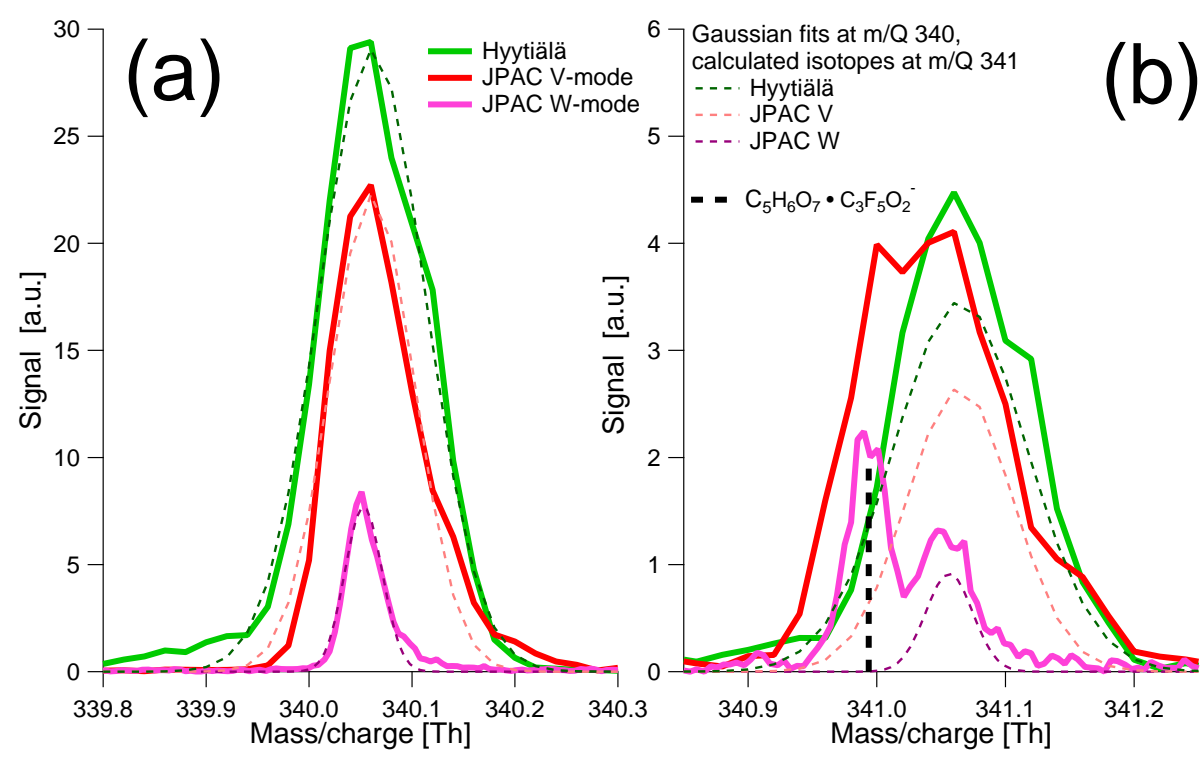

Fig. 4. Three different spectra, ambient night-time from Hyytiälä (green) and $\alpha$-pinene chamber from JPAC in V-mode (red) and W-mode (purple), at UMR 340 (a) and $341 \mathrm{Th}$ (b). Dashed lines in (a) depict Gaussian fits to the measured data (solid lines). Assuming that the peak at $340 \mathrm{Th}$ is $\mathrm{C}_{10} \mathrm{H}_{14} \mathrm{NO}_{12}^{-}$, the corresponding isotopes at $341 \mathrm{Th}$ are plotted as dashed lines in (b). In Hyytiälä the peak at UMR $341 \mathrm{Th}$ is almost completely explained by the isotope, whereas there is an interfering ion observed in JPAC. This ion was attributed to $\mathrm{C}_{5} \mathrm{H}_{6} \mathrm{O}_{7} \cdot \mathrm{C}_{3} \mathrm{~F}_{5} \mathrm{O}_{2}^{-}$.

the fact that the measured UMR 341 in Hyytialä is larger than the isotope, is to be expected. The only way for the isotopic ratio to disprove the identification of UMR $340 \mathrm{Th}$ would be if the isotopic fit would be larger than the actual signal. For the JPAC data, there is clearly some other ion at UMR $341 \mathrm{Th}$, and with the high resolution of the $\mathrm{W}$ mode measurement, the two peaks separate. Again, the isotopic ratio matches the signal very well. The other ion at UMR 341 has been identified as $\mathrm{C}_{5} \mathrm{H}_{6} \mathrm{O}_{7} \cdot \mathrm{C}_{3} \mathrm{~F}_{5} \mathrm{O}_{2}^{-}$, i.e. a mixed cluster of an organic molecule produced from $\alpha$-pinene, and a fluorinated acid. This identification will be discussed in more detail in the next section. In the $\mathrm{V}$ mode spectrum, this ion causes a shift of the peak towards lower masses, which was already visible in Fig. 2c.

Based on the exact mass, isotopic distribution, and the fact that the precursor is $\mathrm{C}_{10} \mathrm{H}_{16}$, we now conclude that the elemental composition of UMR 340 is $\mathrm{C}_{10} \mathrm{H}_{14} \mathrm{NO}_{12}^{-}$as was originally speculated by Ehn et al. (2010) although this could not at that time be conclusively determined from their data. Also the other ions in the 300-400 Th range are now identified as $\mathrm{C}_{10}$ compounds with one $\mathrm{N}$, and $\mathrm{O}$ ranging from 10 to 16 .

\subsection{Identification of the ions as clusters}

Mass spectrometric methods (with the exception of MS-MS coupled systems) can typically only provide elemental identification and not any molecular information. We could, for example, not normally determine how the $\mathrm{N}$ atom is incorporated in the detected ions. However, in this case, more in- formation is available. The pattern of organics around 300$400 \mathrm{Th}$ in JPAC is in fact duplicated, although at lower intensity, with a shift of $101 \mathrm{Th}$ in the 400-500 Th range. The mass difference corresponds to removal of $\mathrm{NO}_{3}^{-}$(UMR 62) and addition of $\mathrm{C}_{3} \mathrm{~F}_{5} \mathrm{O}_{2}^{-}$(UMR 163). As an example, Fig $4 \mathrm{~b}$ showed a peak at 341 corresponding to $\mathrm{C}_{5} \mathrm{H}_{6} \mathrm{O}_{7} \cdot \mathrm{C}_{3} \mathrm{~F}_{5} \mathrm{O}_{2}^{-}$, and as can be made out in Fig. 1c, there is a lone peak at UMR 240 Th which has been identified as $\mathrm{C}_{5} \mathrm{H}_{6} \mathrm{O}_{7} \cdot \mathrm{NO}_{3}^{-}$. It is believed that $\alpha$-pinene in JPAC is oxidized by ozone and possibly other radicals formed from the reactions of $\alpha$ pinene and ozone, followed by clustering of the highly oxidized multifunctional organic compounds (henceforth abbreviated as $\mathrm{HOMs}$ ) with the existing $\mathrm{NO}_{3}^{-}$ions in the chamber. The HOMs likely have lower gas phase acidities than $\mathrm{HNO}_{3}$, and will thus not be detected by themselves, but they cluster readily with $\mathrm{NO}_{3}^{-}, \mathrm{C}_{3} \mathrm{~F}_{5} \mathrm{O}_{2}^{-}$, and some other fluorinated acids. Artificially increasing the amount of $\mathrm{HNO}_{3}$ in JPAC leads to an increase of the ions from clusters of $\mathrm{NO}_{3}^{-}$with the HOMs, while decreasing the corresponding clusters with $\mathrm{C}_{3} \mathrm{~F}_{5} \mathrm{O}_{2}^{-}$.

Additional evidence for the clustering can be found from Hyytiälä, when comparing the ion spectra during nights with high and low $\mathrm{H}_{2} \mathrm{SO}_{4}$. As an example we will take a closer look at the nights of July 28 and 29, 2010. The first night was a "typical" summer night with northerly wind and fairly clean conditions, whereas by the second night, the wind direction had turned almost southerly, with increases in gas phase pollutants such as $\mathrm{CO}$ and $\mathrm{SO}_{2}$. The increase in $\mathrm{SO}_{2}$ also caused an increase in gaseous $\mathrm{H}_{2} \mathrm{SO}_{4}$, which is detectable as an increase in both $\mathrm{HSO}_{4}^{-}$and $\mathrm{H}_{2} \mathrm{SO}_{4} \cdot \mathrm{HSO}_{4}^{-}$ 


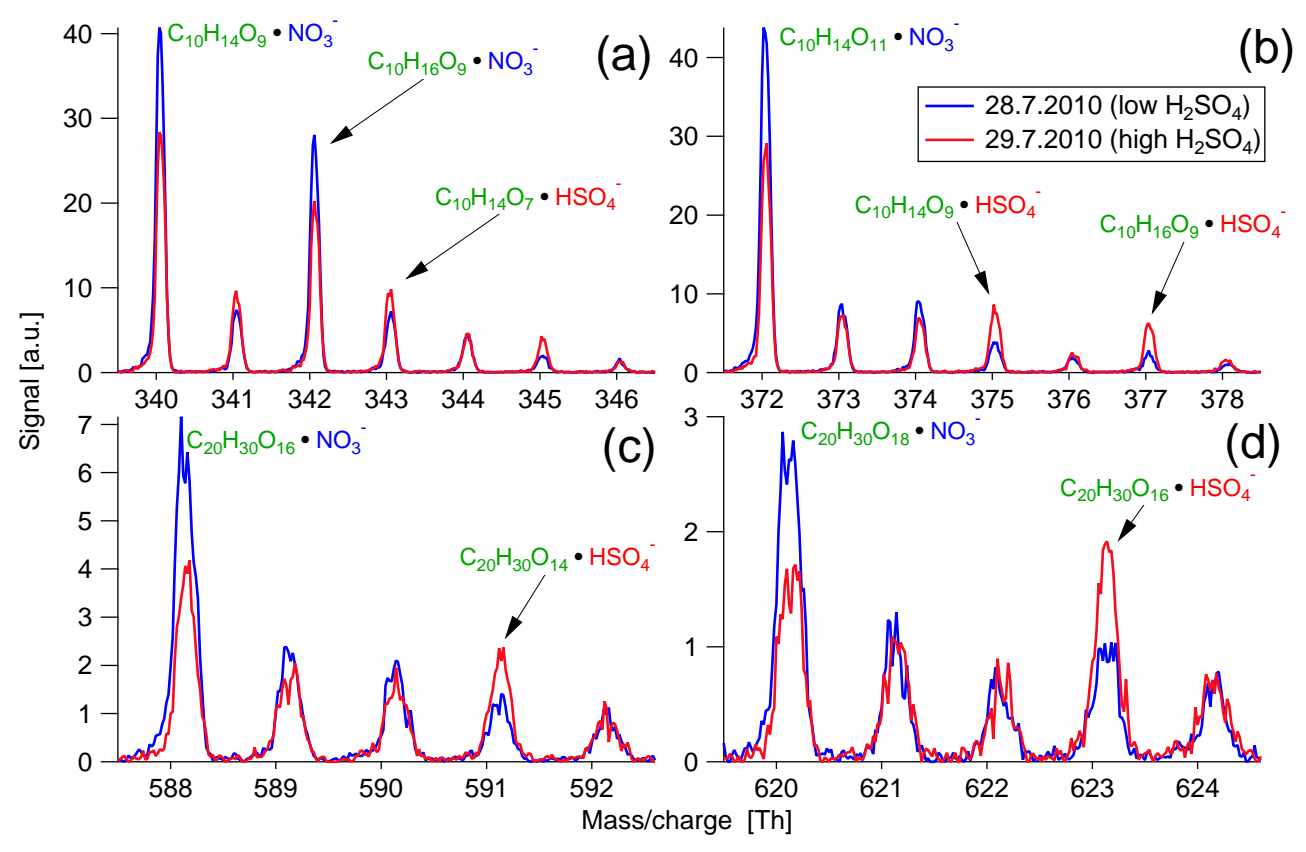

Fig. 5. Comparison of mass spectra during two consecutive nights, where the first was a "normal" night with low $\mathrm{SO}_{2}$ and $\mathrm{H}_{2} \mathrm{SO}_{4}$, but the second had unusually high levels of both. The four subplots show different parts of the ion spectrum, with the aim to show how $\mathrm{HOM} \cdot \mathrm{HSO}_{4}^{-}$clusters increase at the expense of $\mathrm{HOM} \cdot \mathrm{NO}_{3}^{-}$clusters, e.g. UMR $375 \mathrm{Th}\left(\mathrm{C}_{10} \mathrm{H}_{14} \mathrm{O}_{9} \cdot \mathrm{HSO}_{4}^{-}\right)$increases while UMR 340 Th $\left(\mathrm{C}_{10} \mathrm{H}_{14} \mathrm{O}_{9} \cdot \mathrm{NO}_{3}^{-}\right)$decreases.

in the APi-TOF spectra. In the 300-650 Th range, there was an accompanying change in the concentration of certain ions. The majority of this shift is believed to be due to $\mathrm{HSO}_{4}^{-}$displacing $\mathrm{NO}_{3}^{-}$in the clusters with the organics, causing a shift of $35 \mathrm{Th}$ in the spectrum. Some example spectra from the two nights are shown in Fig. 5. In Fig. 5a the large peaks at UMR 340 and $342 \mathrm{Th}$, corresponding to $\mathrm{C}_{10} \mathrm{H}_{14} \mathrm{O}_{9} \cdot \mathrm{NO}_{3}^{-}$and $\mathrm{C}_{10} \mathrm{H}_{16} \mathrm{O}_{9} \cdot \mathrm{NO}_{3}^{-}$, both decrease. Simultaneously UMR 343 (corresponding to $\mathrm{C}_{10} \mathrm{H}_{14} \mathrm{O}_{7} \cdot \mathrm{HSO}_{4}^{-}$) increases, while the corresponding cluster with $\mathrm{NO}_{3}^{-}$at UMR $308 \mathrm{Th}$ decreases (not shown). In Fig. 5b, UMR $372\left(\mathrm{C}_{10} \mathrm{H}_{14} \mathrm{O}_{11} \cdot \mathrm{NO}_{3}^{-}\right)$drops, whereas UMR 375 and $377 \mathrm{Th}$ (corresponding to the ions at 340 and $342 \mathrm{Th}$ in Fig. 5a with displacement of $\mathrm{NO}_{3}^{-}$by $\mathrm{HSO}_{4}^{-}$) increase.

Although lower signals, also the ions at 500-650 Th show this same feature. These ions typically contain 16-20 C atoms, and are thus believed to be some form of dimers of HOMs typically found in the 300-400 Th range. The dimers typically have slightly lower $\mathrm{O} / \mathrm{C}$ ratios than the monomers. Ions identified as clusters with $\mathrm{NO}_{3}^{-}$, such as UMR 588 and $620 \mathrm{Th}$, decrease while e.g. UMR $623(588+35)$ Th increases (Fig. $5 \mathrm{c}$ and d). The signal-to-noise for these peaks is not good enough to provide conclusive identification of the ions at the highest masses, but the high-resolution data certainly do not contradict the suggested explanation. Also other ions that were not shown in Fig. 5 follow the pattern marked out above.
In summary, by using all the above-mentioned methods, a number of ions were identified. As seen already in Fig. 1, the most abundant ions are observed around 300-400 Th, but an additional group is clearly visible at $500-650 \mathrm{Th}$. Based on the elemental composition, these two groups are termed "monomers" and "dimers" and the most abundant molecules in both groups are listed in Appendix A (Tables A1 and A2).

\section{Discussion}

\subsection{Possible formation mechanisms}

The high level of oxidation of $\alpha$ - and $\beta$-pinene ozonolysis products that is seen in Table A1 and A2 has, to our knowledge, not been previously measured nor predicted in the gas phase. Indeed, the mechanism forming these molecules is still unclear, and we can only draw some preliminary conclusions based on the available data.

The HOMs need to be formed in the gas phase, and not through particle phase reactions, as the TSI 3025 condensation particle counter (with a $d_{50}$ cut-off diameter of roughly $3 \mathrm{~nm}$ ) always showed particle counts $<10 \mathrm{~cm}^{-3}$ during the experiments in JPAC. Furthermore, the HOMs observed in this work are expected to have such low vapor pressures that they will not re-evaporate from a particle or surface, suggesting that chamber wall effects can also be discarded.

While $\beta$-pinene produced mainly $\mathrm{C}_{9}$ compounds, $\alpha$ pinene produced mostly $\mathrm{C}_{10}$ compounds. This is a result of 
the first reaction step where ozone attacks the double bonds in the pinene molecules. In $\alpha$-pinene the double bond is part of a ring, and thus merely breaking that bond will not cause fragmentation. On the other hand, when ozone attacks the exocyclic double bond in $\beta$-pinene, one $\mathrm{C}$ is inevitably lost. These ozone reactions also produce Criegee or $\mathrm{OH}$ radicals, which can play a role in the oxidation processes leading up to some of the observed HOMs.

Other HOM compounds have previously been identified in SOA samples from chamber oxidation experiments of $\alpha$ pinene (Claeys et al., 2007; Warscheid and Hoffmann, 2002; Iinuma et al., 2004). Although less oxidized than the HOMs found in this study, the compounds proposed by the authors had relatively high $\mathrm{O} / \mathrm{C}$ (typically $\mathrm{C}_{9}$ and $\mathrm{C}_{10}$ compounds with up to 5 or $6 \mathrm{O}$ atoms). The level of oxidation was achieved mainly by carboxylic acid groups, and in one case also by ester formation (Warscheid and Hoffmann, 2002). HOMs are also formulated in the Master Chemical Mechanism MCM (Jenkin et al., 1997; Saunders et al., 2003) where they contain functional groups like hydroperoxides ($\mathrm{OOH})$, carboxyls $(-\mathrm{COOH})$, peroxycarboxyls $(-\mathrm{C}(\mathrm{O}) \mathrm{OOH})$, and carbonyl groups $(>\mathrm{C}=\mathrm{O})$. For the observed large degree of oxygenation at high hydrogen atom contents, eventually hydroperoxide (-OOH) or hydroxyl (-OH) groups are needed, as solely increasing the number of carbonyl or carboxyl groups will increase the $\mathrm{O} / \mathrm{C}$ as desired but decrease the $\mathrm{H} / \mathrm{C}$.

Aqueous reactions in aerosol particles have been shown to produce high molecular weight $\mathrm{HOMs}$ with $\mathrm{O} / \mathrm{C}>1$ through oligomerization of $\mathrm{C}_{2}$ and $\mathrm{C}_{3}$ compounds, but these HOMs comprised a wide range of carbon numbers, also exceeding $\mathrm{C}_{10}$ (Lim et al., 2010). Although fragmentation is a possibility at each oxidation step, it is highly unlikely that the gas-phase HOMs observed in this work would be clusters or oligomers of fragmentation products, as most of them contain the same amount of $\mathrm{C}$ as the precursor molecules. As in the case of the reactions reported by Lim et al. (2010), oligomerization would produce a variety of different carbon numbers. In our work, no molecules with 11 or more $\mathrm{C}$ were identified in the 300-400 Th range, though some probable fragments were detected between 200 and $300 \mathrm{Th}$. Specifically $\mathrm{C}_{5} \mathrm{H}_{6} \mathrm{O}_{7} \cdot \mathrm{NO}_{3}^{-}$detected at UMR $240 \mathrm{Th}$ was very common, and can be distinguished in Fig. 1c and 1d. The O/C ratio of this molecule is as high as 1.4 , but the $\mathrm{H} / \mathrm{C}$ is fairly low, suggesting that this molecule could be a tri-carboxylic acid. Also the detected $\mathrm{C}_{7}, \mathrm{C}_{8}$ and $\mathrm{C}_{9}$ oxidation products from $\alpha$ pinene can be formed from oxidation reactions splitting off one or two terminal $\mathrm{C}$ atoms, or e.g. acetone $\left(\mathrm{C}_{3} \mathrm{H}_{6} \mathrm{O}\right)$.

As the molecules are detected in the natural negative ion spectrum, they are expected to contain carboxylic groups, though the favorable cluster formation with $\mathrm{NO}_{3}^{-}$can possibly also be due to other, unknown structures. With all the $\mathrm{O}$ atoms in carboxylic acid groups, the number of $\mathrm{H}$ atoms becomes lower than observed in the ions. Although this paper does not attempt to provide any molecular structures for the observed HOMs, we can speculate over which functional groups that could produce the high $\mathrm{O} / \mathrm{C}$ and $\mathrm{H} / \mathrm{C}$ ratios. One structural element that fits the criteria is the geminal diol, formed through the addition of water to the carbonyl groups,

$-\mathrm{CHO} \stackrel{\mathrm{H}_{2} \mathrm{O}}{\longrightarrow}-\mathrm{CH}(\mathrm{OH})_{2}$.

This reaction is known to occur in aqueous environments such as cloud droplets, but has also recently been observed to take place in the gas-phase for the cases of methylglyoxal (Axson et al., 2010) and glyoxylic acid (Plath et al., 2009). Another structural element that can add $\mathrm{O}$ without decreasing the $\mathrm{H}$ atom content is the hydroperoxide group. Both model and experimental studies have found organic peroxides to be important contributors to SOA (e.g. Reinnig et al., 2009; Chen et al., 2011). It can also not be ruled out that the $\mathrm{HOM} \cdot \mathrm{NO}_{3}^{-}$clusters can contain non-covalently bound water molecules, but as mentioned previously, water molecules have not been observed at any significant amounts with any other ions. The main peaks in our spectra are typically separated by $16 \mathrm{Th}(\mathrm{O})$ and not $18 \mathrm{Th}\left(\mathrm{H}_{2} \mathrm{O}\right)$, suggesting that water clusters are not able to explain the high oxygen content of the HOMs. Additionally, if indeed water molecules clustered efficiently with the HOMs, one would still need to remove so many $\mathrm{H}_{2} \mathrm{O}$ molecules that one would reach unreasonably low $\mathrm{H} / \mathrm{C}$ ratios before achieving more commonly measured $\mathrm{O} / \mathrm{C}$ ratios.

The molecules in the 500-650 Th range were termed dimers due to the number of carbon atoms in the molecules. The main peaks have 16-20 C atoms suggesting that they are products of two oxidized pinene molecules. The formation mechanism of these dimers is still unknown, however, the dimers can typically not be considered simply non-covalently bonded clusters of two of the observed monomers, as the dimer compositions can rarely be found by just adding together two monomers. Thus, the current hypothesis is that these are large molecules formed from reactions of two oxidized monomers, possibly undergoing further oxidation after the dimerization. Less oxidized HOM dimers have been reported in $\mathrm{SOA}$, with an often discussed product at $\mathrm{C}_{17} \mathrm{H}_{26} \mathrm{O}_{8}$ (Hoffmann et al., 1998; Yasmeen et al., 2010). As listed in Table A2, we detected $\mathrm{C}_{17} \mathrm{H}_{26} \mathrm{O}_{n}$, with $n$ in the range 11-16.

\subsection{Estimation of neutral HOM concentrations}

Naturally charged ions can only in very specific cases be used to calculate the concentration of neutral species. The absolute concentration of an ion, e.g. $\mathrm{NO}_{3}^{-}$, tells almost nothing about the concentration of the corresponding neutral molecules, e.g. $\mathrm{HNO}_{3}$. This is because the production and loss of charges in the atmosphere depend mainly on properties that do not relate to atmospheric trace gas concentrations (e.g. cosmic radiation and radon concentration for ion production, and aerosol particle surface area acting as an ion sink). However, though $\mathrm{NO}_{3}^{-}$does not track 
the $\mathrm{HNO}_{3}$ concentration, it was found during the measurements in Hyytiälä that the nitric acid dimer-to-monomer ratio $\left(\mathrm{HNO}_{3} \cdot \mathrm{NO}_{3}^{-} / \mathrm{NO}_{3}^{-}\right)$did correlate with $\mathrm{HNO}_{3}$, suggesting that for some species the natural ion spectrum can be used to for estimates of neutral concentration.

In the specific case of sulfuric acid, Eisele (1989b) estimated $\left[\mathrm{H}_{2} \mathrm{SO}_{4}\right]$ from ion spectra using a few simple assumptions. Firstly, $\mathrm{HSO}_{4}^{-}$was mainly formed from $\mathrm{NO}_{3}^{-}+$ $\mathrm{H}_{2} \mathrm{SO}_{4}$, with a known rate coefficient (Viggiano et al., 1982). Secondly, the rate coefficient for the loss of $\mathrm{HSO}_{4}^{-}$could be calculated as the reciprocal of the ion lifetime, which was assumed to be $100 \mathrm{~s}$, since $\mathrm{HSO}_{4}^{-}$is considered a "terminal" ion that will not be lost due to charge transfer to stronger acids. A similar calculation for any other, "non-terminal" ion species becomes more complicated. For example malonic acid is a stronger acid than $\mathrm{HNO}_{3}$ in the gas phase, but still weaker than $\mathrm{H}_{2} \mathrm{SO}_{4}$ (Ehn et al., 2010). For this estimation, one would require knowledge of the rate coefficient of malonic acid with $\mathrm{NO}_{3}^{-}$, but also the loss rate by reaction with $\mathrm{H}_{2} \mathrm{SO}_{4}$ needs to be known. For weaker acids the calculation becomes increasingly more complex as more and more reaction rates and concentrations need to be estimated.

With similar methods as described above we group all the HOMs observed in the ion spectra in Hyytiälä, and will attempt to estimate the total neutral concentration. A prerequisite for this is that we are in a low-OH regime, which means that the concentrations of strong acids such as $\mathrm{H}_{2} \mathrm{SO}_{4}, \mathrm{HNO}_{3}$ and malonic acid are low enough not to dominate the spectrum, but $\mathrm{HNO}_{3}$ is high enough to form $\mathrm{NO}_{3}^{-}$ions for clustering with the organics. We assume that the $\mathrm{HOM} \cdot \mathrm{NO}_{3}^{-}$clusters are formed by collision of $\mathrm{NO}_{3}^{-}$with the $\mathrm{HOM}$. The loss of the ion clusters occurs through ion-ion recombination, coagulation with aerosol particles, and charge transfer to stronger acids. In steady-state the formation and loss are equal, and we get

$k_{1}\left[\mathrm{NO}_{3}^{-}\right][\mathrm{HOM}]=\left(k_{\mathrm{rec}}+k_{\mathrm{coag}}+\sum_{i} k_{\mathrm{CT}}^{i}\right)\left[\mathrm{HOM} \cdot \mathrm{NO}_{3}^{-}\right]$,

where $k_{1}$ is the rate coefficient of the forward reaction $\mathrm{NO}_{3}^{-}$ $+\mathrm{HOM} \rightarrow \mathrm{HOM} \cdot \mathrm{NO}_{3}^{-}, k_{\text {rec }}$ is the rate coefficient of loss by ion-ion recombination, $k_{\text {coag }}$ by coagulation, and $k_{\mathrm{CT}}^{i}$ correspond to loss due to charge transfer to the stronger acid $i$. The coagulation sink is a function of the aerosol size distribution, and for this calculation it is implicitly included in $k_{\text {coag. }}$. Here HOM refers only to the group of extremely oxidized molecules detected in the ion spectra by clustering with $\mathrm{NO}_{3}^{-}$. Solving for $[\mathrm{HOM}]$ yields

$$
[\mathrm{HOM}]=\frac{\left(k_{\mathrm{rec}}+k_{\mathrm{coag}}+\sum_{i} k_{\mathrm{CT}}^{i}\right)\left[\mathrm{HOM} \cdot \mathrm{NO}_{3}^{-}\right]}{k_{1}\left[\mathrm{NO}_{3}^{-}\right]} .
$$

To estimate a lower limit for [HOM], we will use lower limit estimates for the numerator and upper limit estimates for the denominator in Eq. (4). To minimize the loss rate coefficients, we will assume that the loss is the reciprocal of the ion lifetime, and assume an upper range lifetime estimate of $10 \mathrm{~min}$. For comparison, Eisele (1989b) used an ion lifetime of 100s for similar calculations, and Dal Maso et al. (2002) reported average condensation sink values in Hyytiälä corresponding to (neutral) vapor lifetimes of $140-250 \mathrm{~s}$. Thus,

$$
\begin{aligned}
& k_{\text {lifetime }} \equiv\left(k_{\text {rec }}+k_{\text {coag }}+\sum_{i} k_{\mathrm{CO}}^{i}\right) \approx(10 \mathrm{~min})^{-1} \\
& =0.0016667 \mathrm{~s}^{-1} .
\end{aligned}
$$

For $k_{1}$ we will use the collision limit for an upper limit of possible reaction rates $\left(3 \times 10^{-9} \mathrm{~cm}^{3} \mathrm{~s}^{-1}\right)$.

Finally, the ratio of the clusters to pure $\mathrm{NO}_{3}^{-}$is estimated from the experimental data by summing over all the identified $\mathrm{HOM} \cdot \mathrm{NO}_{3}^{-}$ions and dividing by the $\mathrm{NO}_{3}^{-}$signal, yielding $\left[\mathrm{HOM} \cdot \mathrm{NO}_{3}^{-}\right] /\left[\mathrm{NO}_{3}^{-}\right] \approx 5$, which again is a lower range estimate. This then yields a lower limit of the concentration of the highly oxidized organics:

$$
\begin{aligned}
& {[\mathrm{HOM}] \approx \frac{k_{\text {lifetime }}\left[\mathrm{HOM} \cdot \mathrm{NO}_{3}^{-}\right]}{k_{1}\left[\mathrm{NO}_{3}^{-}\right]} \approx \frac{0.0016667 \mathrm{~s}^{-1} \cdot 5}{3 \times 10^{-9} \mathrm{~cm}^{3} \mathrm{~s}^{-1}}} \\
& =2.78 \times 10^{6} \mathrm{~cm}^{-3} \approx 0.1 \mathrm{ppt} .
\end{aligned}
$$

A corresponding upper limit estimate is harder to calculate, mainly due to the problems in constraining the rate coefficients. Collision probabilities and steric factors depend on the exact molecules under consideration, and can have a large influence on $k_{1}$. However, reasonable changes in $k_{1}$, $k_{\text {lifetime }}$ and $\left[\mathrm{HOM} \cdot \mathrm{NO}_{3}^{-}\right] /\left[\mathrm{NO}_{3}^{-}\right]$can easily yield concentrations above 1ppt. Fragmentation of $\mathrm{HOM} \cdot \mathrm{NO}_{3}^{-}$clusters to pure $\mathrm{NO}_{3}^{-}$inside the instrument would also lead to an underestimation of the concentration. On the other hand, the exact mass/charge dependent transmission of the instrument was not determined during the measurements, and could have an influence on the $\left[\mathrm{HOM} \cdot \mathrm{NO}_{3}^{-}\right] /\left[\mathrm{NO}_{3}^{-}\right]$ratio in either direction, though a decrease is more likely. Thus, our best estimate of the typical abundance of the extremely oxidized organics at night in the boreal forest is between 0.1 and a few ppt.

As a comparison, Ehn et al. (2010) found that the negative ion distribution in Hyytiälä was practically completely dominated by $\mathrm{H}_{2} \mathrm{SO}_{4}$-related ions when the gaseous $\mathrm{H}_{2} \mathrm{SO}_{4}$ concentration reached $1 \mathrm{ppt}$. On the other hand, during nights when the $\mathrm{H}_{2} \mathrm{SO}_{4}$ dropped to below $\sim 10^{5} \mathrm{~cm}^{-3}$ (roughly $0.01 \mathrm{ppt}$ ), the $\mathrm{HSO}_{4}^{-}$contribution to the ion spectrum was on the order of a percent since the ion lifetimes were not long enough to allow collisions of the ions with $\mathrm{H}_{2} \mathrm{SO}_{4}$ molecules. Replacing $\mathrm{HOM} \cdot \mathrm{NO}_{3}^{-}$with $\mathrm{HSO}_{4}^{-}$in all the calculations above would thus have given the correct order of magnitude estimates for $\left[\mathrm{H}_{2} \mathrm{SO}_{4}\right]$. As our night-time spectra were fairly dominated by the $\mathrm{HOM} \cdot \mathrm{NO}_{3}^{-}$clusters, it is fair to assume that the concentrations are in the $10^{6}-10^{7} \mathrm{~cm}^{-3}(\sim 0.1-1 \mathrm{ppt})$ range, or possibly even higher. 


\subsection{Atmospheric relevance}

Assuming the sum of the HOMs is around 1ppt, this is higher than e.g. the typical concentration of $\mathrm{H}_{2} \mathrm{SO}_{4}$ in the boreal forest (Petäjä et al., 2009), and while the mass of the molecules are roughly 3 times larger (even more for the dimers) than that of $\mathrm{H}_{2} \mathrm{SO}_{4}$, their role in aerosol mass formation alone could be of importance. In addition to this, the role in nucleation and initial growth of nanometer-sized clusters needs to be further investigated. The vapor pressures of the molecules, due to their size and high degree of oxidation, are expected to be extremely low. As previously stated, in the dark ozonolysis experiments, no particle formation occurred although the monomers were detected. However, the low-range cut-off of the particle counter used for particle detection was $3 \mathrm{~nm}$, which does not rule out some cluster formation taking place, without the clusters having time to grow large enough before being flushed out of the chamber.

The gas-phase dimers observed in this study are probably clearly lower in abundance than the oxidized monomers, but due to their large sizes may also be very efficient at condensing onto small newly formed particles, or even taking place in the initial formation.

It is possible that these organics are present also during day-time, and this is an important point to study in the future. If the molecules are only abundant at night, they might still be relevant for SOA (mass) formation. Although rare, and with growth usually ending below $10 \mathrm{~nm}$, nocturnal NPF events also occur in Hyytiälä (Junninen et al., 2008), and the highly oxidized organics may play an important role in these events. Furthermore, these compounds could possibly explain some of the night-time high concentrations of sub- $3 \mathrm{~nm}$ particle concentrations observed with a pulse-height condensation particle counter (Lehtipalo et al., 2011; Sipilä et al., 2008).

\section{Conclusions}

A previously unidentified group of highly oxidized multifunctional molecules (HOMs) were observed in the naturally charged negative ion spectra in both ambient air (Hyytiälä) and during $\alpha$ - and $\beta$-pinene chamber ozonolysis experiments. These HOMs retained practically all of their original 10 carbon atoms, while reaching $\mathrm{O} / \mathrm{C}$ ratios of $0.7-1.3$. Through dedicated experiments in the Jülich plant atmosphere chamber, the elemental composition of these organics was conclusively determined. Both the exact mass and isotopic ratios in high-resolution spectra were used for the identification. Furthermore, the ions could be identified as clusters of HOMs and deprotonated inorganic acids (mainly $\mathrm{HNO}_{3}$, but also $\mathrm{C}_{3} \mathrm{~F}_{5} \mathrm{HO}_{2}$ and $\mathrm{H}_{2} \mathrm{SO}_{4}$ ).

The concentration of neutral HOMs could only be estimated using several assumptions. Based on a rough estimation, the concentration of these extremely oxidized molecules in the night-time boreal forest is typically on the order of 0.1 $1 \mathrm{ppt}$. The yield of these molecules at higher $\mathrm{OH}$ concentrations is yet to be determined, but this cannot be done from the ion spectra due to the signal spreading out over many more peaks, likely due to the formation of many more compounds that compete for the limited amount of charges.

Even at concentrations of $0.1-1 \mathrm{ppt}$, these molecules may have an important impact on aerosols due to their presumably low vapor pressures. Mainly the first steps of new particle formation through nucleation and growth may be influenced by these compounds, as they are present at similar concentrations as $\mathrm{H}_{2} \mathrm{SO}_{4}$ which is widely accepted to take part in nucleation of new particles, but already have roughly 3 times the mass. Furthermore, the existence of such highly oxidized species may suggest that some of the observed missing $\mathrm{OH}$ reactivity could be explained by VOC oxidation products reacting several times with $\mathrm{OH}$.

The exact formation mechanism of the HOMs is still unknown. However, the oxidation most likely takes place in the gas phase and we hypothesize that formation of carbonyl groups, followed by water addition forming carbonyl hydrates (geminal diols), may be involved. Further work will include trying to quantitatively measure the molecules using chemical ionization techniques under different conditions. If successful, this should provide a better picture of both what drives their formation, and of their atmospheric importance.

\section{Appendix A}

\section{Peak list}

In this appendix we list the most abundant HOMs detected in this study. As all of the molecules were mainly detected in clusters with $\mathrm{NO}_{3}^{-}$, this is omitted and the first column in both tables lists the elemental composition of the organic molecules that were found in the clusters. The list is not exhaustive, but does contain the most abundant detected molecules. The typically largest peaks in Hyytiälä and in JPAC $\alpha$-pinene experiments are highlighted in bold in Table 1 . The second column of the table shows the mass-tocharge at which the ion clusters were detected, the third the mass of the HOM in the cluster, and columns 4-6 show where this molecule has been detected. 
Table A1. List of observed monomers detected in Hyytiälä and JPAC. An "X" means that the identification is fairly unambiguous, a blank means that the ion has not been detected, and "/" means that the ion might be present, but could not be identified due to insufficient signal or overlapping peaks from other compounds.

\begin{tabular}{|c|c|c|c|c|c|c|c|}
\hline \multicolumn{3}{|c|}{ Elemental formula } & \multirow{2}{*}{$\begin{array}{c}\text { Ion mass-to-charge } \\
\text { (clustered with } \mathrm{NO}_{3}^{-} \text {) } \\
{[\mathrm{Th}]}\end{array}$} & \multirow{2}{*}{$\begin{array}{c}\text { HOM mass } \\
{[\mathrm{Da}]}\end{array}$} & \multicolumn{3}{|c|}{ Detected in } \\
\hline & & & & & Hyytiälä & JPAC $\alpha$-pinene & JPAC $\beta$-pinene \\
\hline $\mathrm{C}_{7}$ & $\mathrm{H}_{10}$ & $\mathrm{O}_{4}$ & 220.046 & 158.058 & & $X$ & $X$ \\
\hline $\mathrm{C}_{5}$ & $\mathrm{H}_{6}$ & $\mathrm{O}_{6}$ & 224.005 & 162.017 & $\mathrm{X}$ & $X$ & $X$ \\
\hline $\mathrm{C}_{5}$ & $\mathrm{H}_{6}$ & $\mathrm{O}_{7}$ & 240.000 & 178.012 & $\mathrm{X}$ & $X$ & $X$ \\
\hline $\mathrm{C}_{7}$ & $\mathrm{H}_{8}$ & $\mathrm{O}_{8}$ & 282.010 & 220.022 & & $X$ & 1 \\
\hline $\mathrm{C}_{8}$ & $\mathrm{H}_{12}$ & $\mathrm{O}_{7}$ & 282.047 & 220.059 & $\mathrm{X}$ & $X$ & 1 \\
\hline $\mathrm{C}_{8}$ & $\mathrm{H}_{12}$ & $\mathrm{O}_{8}$ & 298.042 & 236.054 & $\mathrm{X}$ & $X$ & 1 \\
\hline $\mathbf{C}_{10}$ & $\mathbf{H}_{14}$ & $\mathbf{O}_{7}$ & 308.062 & 246.074 & $\mathrm{X}$ & $X$ & 1 \\
\hline $\mathrm{C}_{9}$ & $\mathrm{H}_{12}$ & $\mathrm{O}_{8}$ & 310.042 & 248.054 & & & $X$ \\
\hline $\mathrm{C}_{10}$ & $\mathrm{H}_{16}$ & $\mathrm{O}_{7}$ & 310.078 & 248.090 & & $X$ & \\
\hline $\mathrm{C}_{8}$ & $\mathrm{H}_{12}$ & $\mathrm{O}_{9}$ & 314.036 & 252.048 & & $X$ & $X$ \\
\hline $\mathrm{C}_{10}$ & $\mathrm{H}_{14}$ & $\mathrm{O}_{8}$ & 324.057 & 262.069 & & $X$ & \\
\hline $\mathrm{C}_{10}$ & $\mathrm{H}_{16}$ & $\mathrm{O}_{8}$ & 326.073 & 264.085 & 1 & $X$ & \\
\hline $\mathrm{C}_{9}$ & $\mathrm{H}_{12}$ & $\mathrm{O}_{9}$ & 326.036 & 264.048 & 1 & $\mathrm{X}$ & $\mathrm{X}$ \\
\hline $\mathrm{C}_{9}$ & $\mathrm{H}_{14}$ & $\mathrm{O}_{9}$ & 328.052 & 266.064 & & $\mathrm{X}$ & 1 \\
\hline $\mathbf{C}_{10}$ & $\mathbf{H}_{14}$ & $\mathbf{O}_{9}$ & 340.052 & 278.064 & $\mathrm{X}$ & $\mathrm{X}$ & \\
\hline $\mathrm{C}_{9}$ & $\mathrm{H}_{12}$ & $\mathrm{O}_{10}$ & 342.031 & 280.043 & 1 & & $X$ \\
\hline $\mathbf{C}_{10}$ & $\mathrm{H}_{16}$ & $O_{9}$ & 342.068 & 280.080 & $\mathrm{X}$ & $X$ & 1 \\
\hline $\mathrm{C}_{10}$ & $\mathrm{H}_{14}$ & $\mathrm{O}_{10}$ & 356.047 & 294.059 & & & \\
\hline $\mathrm{C}_{10}$ & $\mathrm{H}_{16}$ & $\mathrm{O}_{10}$ & 358.063 & 296.075 & $\mathrm{X}$ & $X$ & \\
\hline $\mathrm{C}_{9}$ & $\mathrm{H}_{12}$ & $\mathrm{O}_{11}$ & 358.026 & 296.038 & & & $X$ \\
\hline $\mathrm{C}_{10}$ & $\mathrm{H}_{14}$ & $O_{11}$ & 372.042 & 310.054 & $\mathrm{X}$ & $X$ & $X$ \\
\hline $\mathrm{C}_{10}$ & $\mathrm{H}_{16}$ & $\mathrm{O}_{11}$ & 374.058 & 312.070 & $X$ & $X$ & \\
\hline $\mathrm{C}_{9}$ & $\mathrm{H}_{12}$ & $\mathrm{O}_{12}$ & 374.021 & 312.033 & & & $\mathrm{X}$ \\
\hline $\mathrm{C}_{10}$ & $\mathrm{H}_{14}$ & $\mathrm{O}_{13}$ & 404.032 & 342.044 & $\mathrm{X}$ & $X$ & \\
\hline
\end{tabular}

Table A2. List of observed dimers detected in Hyyitälä and JPAC. An "X" means that the identification is fairly unambiguous, a blank means that the ion has not been detected, and "/" means that the ion might be present, but could not be identified due to insufficient signal or overlapping peaks from other compounds.

\begin{tabular}{|c|c|c|c|c|c|c|c|}
\hline \multicolumn{3}{|c|}{ Elemental formula } & \multirow{2}{*}{$\begin{array}{c}\text { Ion mass-to-charge } \\
\text { (clustered with } \mathrm{NO}_{3}^{-} \text {) } \\
{[\mathrm{Th}]}\end{array}$} & \multirow{2}{*}{$\begin{array}{c}\text { HOM mass } \\
{[\mathrm{Da}]}\end{array}$} & \multicolumn{3}{|c|}{ Detected in } \\
\hline & & & & & Hyytiälä & JPAC $\alpha$-pinene & JPAC $\beta$-pinene \\
\hline $\mathrm{C}_{17}$ & $\mathrm{H}_{26}$ & $\mathrm{O}_{11}$ & 468.136 & 406.148 & & & $X$ \\
\hline $\mathrm{C}_{18}$ & $\mathrm{H}_{26}$ & $\mathrm{O}_{11}$ & 480.136 & 418.148 & & & $\mathrm{X}$ \\
\hline $\mathrm{C}_{14}$ & $\mathrm{H}_{20}$ & $\mathrm{O}_{15}$ & 490.069 & 428.081 & $\mathrm{X}$ & $\mathrm{X}$ & \\
\hline $\mathrm{C}_{19}$ & $\mathrm{H}_{28}$ & $\mathrm{O}_{11}$ & 494.152 & 432.164 & $\mathrm{X}$ & $\mathrm{X}$ & \\
\hline $\mathrm{C}_{20}$ & $\mathrm{H}_{32}$ & $\mathrm{O}_{11}$ & 510.183 & 448.195 & 1 & $\mathrm{X}$ & \\
\hline $\mathrm{C}_{17}$ & $\mathrm{H}_{26}$ & $\mathrm{O}_{14}$ & 516.121 & 454.133 & & & $\mathrm{X}$ \\
\hline $\mathrm{C}_{20}$ & $\mathrm{H}_{30}$ & $\mathrm{O}_{12}$ & 524.162 & 462.174 & $\mathrm{X}$ & $\mathrm{X}$ & \\
\hline $\mathrm{C}_{19}$ & $\mathrm{H}_{28}$ & $\mathrm{O}_{13}$ & 526.141 & 464.153 & $\mathrm{X}$ & 1 & \\
\hline $\mathrm{C}_{18}$ & $\mathrm{H}_{26}$ & $\mathrm{O}_{14}$ & 528.121 & 466.133 & & & $\mathrm{X}$ \\
\hline $\mathrm{C}_{18}$ & $\mathrm{H}_{28}$ & $\mathrm{O}_{14}$ & 530.136 & 468.148 & & $X$ & \\
\hline $\mathrm{C}_{17}$ & $\mathrm{H}_{26}$ & $\mathrm{O}_{15}$ & 532.116 & 470.128 & & & $\mathrm{X}$ \\
\hline $\mathrm{C}_{20}$ & $\mathrm{H}_{30}$ & $\mathrm{O}_{13}$ & 540.157 & 478.169 & & $\mathrm{X}$ & \\
\hline $\mathrm{C}_{20}$ & $\mathrm{H}_{32}$ & $\mathrm{O}_{13}$ & 542.173 & 480.185 & $\backslash$ & $\mathrm{X}$ & \\
\hline $\mathrm{C}_{17}$ & $\mathrm{H}_{26}$ & $\mathrm{O}_{16}$ & 548.110 & 486.122 & & & $\mathrm{X}$ \\
\hline $\mathrm{C}_{20}$ & $\mathrm{H}_{30}$ & $\mathrm{O}_{14}$ & 556.152 & 494.164 & $X$ & $X$ & \\
\hline $\mathrm{C}_{18}$ & $\mathrm{H}_{28}$ & $\mathrm{O}_{16}$ & 562.126 & 500.138 & & $\mathrm{X}$ & \\
\hline $\mathrm{C}_{20}$ & $\mathrm{H}_{30}$ & $\mathrm{O}_{15}$ & 572.147 & 510.159 & & $\mathrm{X}$ & \\
\hline $\mathrm{C}_{20}$ & $\mathrm{H}_{32}$ & $\mathrm{O}_{15}$ & 574.162 & 512.174 & 1 & $\mathrm{X}$ & \\
\hline $\mathrm{C}_{20}$ & $\mathrm{H}_{30}$ & $\mathrm{O}_{16}$ & 588.142 & 526.154 & $\mathrm{X}$ & $X$ & \\
\hline $\mathrm{C}_{18}$ & $\mathrm{H}_{28}$ & $\mathrm{O}_{18}$ & 594.116 & 532.128 & & $\mathrm{X}$ & \\
\hline $\mathrm{C}_{20}$ & $\mathrm{H}_{30}$ & $\mathrm{O}_{18}$ & 620.132 & 558.144 & $\mathrm{X}$ & $X$ & \\
\hline
\end{tabular}


Acknowledgements. M. E. gratefully acknowledges financial support by the Emil Aaltonen foundation. This work was supported by the ERC Advanced Grant EU-FP7-ATMNUCLE (project no 227463), and by the Academy of Finland Center of Excellence program (project no 1118615).

Edited by: R. Holzinger

\section{References}

Arnold, F.: Atmospheric ions and aerosol formation, Space Sci. Rev., 137, 225-239, doi:10.1007/s11214-008-9390-8, 2008.

Axson, J. L., Takahashi, K., De Haan, D. O., and Vaida, V.: Gas-phase water-mediated equilibrium between methylglyoxal and its geminal diol, P. Natl. Acad. Sci., 107, 6687-6692, doi:10.1073/pnas.0912121107, 2010.

Berndt, T., Stratmann, F., Sipila, M., Vanhanen, J., Petaja, T., Mikkila, J., Gruner, A., Spindler, G., Mauldin, R. L., Curtius, J., Kulmala, M., and Heintzenberg, J.: Laboratory study on new particle formation from the reaction $\mathrm{OH}+\mathrm{SO}_{2}$ : Influence of experimental conditions, $\mathrm{H}_{2} \mathrm{O}$ vapour, $\mathrm{NH}_{3}$ and the amine tertbutylamine on the overall process, Atmos. Chem. Phys., 10, 7101-7116, doi:10.5194/acp-10-7101-2010, 2010.

Chen, Q., Liu, Y., Donahue, N. M., Shilling, J. E., and Martin, S. T.: Particle-phase chemistry of secondary organic material: Modeled compared to measured $\mathrm{O}: \mathrm{C}$ and $\mathrm{H}: \mathrm{C}$ elemental ratios provide constraints, Environ. Sci. Technol., 45, 4763-4770, doi:10.1021/es104398s, 2011.

Claeys, M., Szmigielski, R., Kourtchev, I., Van der Veken, P., Vermeylen, R., Maenhaut, W., Jaoui, M., Kleindienst, T. E., Lewandowski, M., Offenberg, J. H., and Edney, E. O.: Hydroxydicarboxylic acids: Markers for secondary organic aerosol from the photooxidation of alpha-pinene, Environ. Sci. Technol., 41, 1628-1634, doi:10.1021/es0620181, 2007.

Dal Maso, M., Kulmala, M., Riipinen, I., Wagner, R., Hussein, T., Aalto, P. P., and Lehtinen, K. E. J.: Formation and growth of fresh atmospheric aerosols: Eight years of aerosol size distribution data from SMEAR II, Hyytiälä, Finland, Boreal Environ. Res., 10, 323-336, 2005.

Dal Maso, M., Kulmala, M., Lehtinen, K. E. J., Mäkelä, J. M., Aalto, P., and O'Dowd C. D.: Condensation and coagulation sinks and formation of nucleation mode particles in coastal and boreal forest boundary layers. J. Geophys. Res. 107, 8097, doi:10.1029/2001JD001053, 2002.

DeCarlo, P. F., Kimmel, J. R., Trimborn, A., Northway, M. J., Jayne, J. T., Aiken, A. C., Gonin, M., Fuhrer, K., Horvath, T., Docherty, K. S., Worsnop, D. R., and Jimenez, J. L.: Field-deployable, high-resolution, time-of-flight aerosol mass spectrometer, Anal. Chem., 78, 8281-8289, doi:10.1021/Ac061249n, 2006.

Di Carlo, P., Brune, W. H., Martinez, M., Harder, H., Lesher, R., Ren, X. R., Thornberry, T., Carroll, M. A., Young, V., Shepson, P. B., Riemer, D., Apel, E., and Campbell, C.: Missing OH reactivity in a forest: Evidence for unknown reactive biogenic VOCs, Science, 304, 722-725, 2004.

Ehn, M., Petäjä, T., Birmili, W., Junninen, H., Aalto, P., and Kulmala, M.: Non-volatile residuals of newly formed atmospheric particles in the boreal forest, Atmos. Chem. Phys., 7, 677-684, doi:10.5194/acp-7-677-2007, 2007.
Ehn, M., Junninen, H., Petäjä, T., Kurtén, T., Kerminen, V.-M., Schobesberger, S., Manninen, H. E., Ortega, I. K., Vehkamäki, H., Kulmala, M., and Worsnop, D. R.: Composition and temporal behavior of ambient ions in the boreal forest, Atmos. Chem. Phys., 10, 8513-8530, doi:10.5194/acp-10-8513-2010, 2010.

Ehn, M., Junninen, H., Schobesberger, S., Manninen, H. E., Franchin, A., Sipilä, M., Petäjä, T., Kerminen, V.-M., Tammet, H., Mirme, A., Mirme, S., Hõrrak, U., Kulmala, M., and Worsnop, D. R. (2010). An instrumental comparison of mobility and mass measurements of atmospheric small ions, Aerosol Sci. Tech., 45, 499-509, doi:10.1080/02786826.2010.547890, 2011.

Eisele, F. L.: Natural and transmission-line produced positive-ions, J. Geophys. Res., 94, 6309-6318, 1989a.

Eisele, F. L.: Natural and anthropogenic negative ions in the troposphere, J. Geophys. Res., 94, 2183-2196, 1989 b.

Gagné, S., Laakso, L., Petäjä, T., Kerminen, V. M., and Kulmala, M.: Analysis of one year of Ion-DMPS data from the SMEAR II station, Finland, Tellus B, 60, 318-329, doi:10.1111/j.16000889.2008.00347, 2008.

Goldstein, A. H., and Galbally, I. E.: Known and unexplored organic constituents in the earth's atmosphere, Environ. Sci. Technol., 41, 1514-1521, 2007.

Hakola, H., Tarvainen, V., Laurila, T., Hiltunen, V., Hellen, H., and Keronen, P.: Seasonal variation of VOC concentrations above a boreal coniferous forest, Atmos. Environ., 37, 1623-1634, 2003.

Hallquist, M., Wenger, J. C., Baltensperger, U., Rudich, Y., Simpson, D., Claeys, M., Dommen, J., Donahue, N. M., George, C., Goldstein, A. H., Hamilton, J. F., Herrmann, H., Hoffmann, T., Iinuma, Y., Jang, M., Jenkin, M. E., Jimenez, J. L., KiendlerScharr, A., Maenhaut, W., McFiggans, G., Mentel, T. F., Monod, A., Prevot, A. S. H., Seinfeld, J. H., Surratt, J. D., Szmigielski, R., and Wildt, J.: The formation, properties and impact of secondary organic aerosol: Current and emerging issues, Atmos. Chem. Phys., 9, 5155-5236, doi:10.5194/acp-9-5155-2009, 2009.

Hari, P. and Kulmala, M.: Station for measuring ecosystematmosphere relations (SMEAR II), Boreal Environ. Res., 10, 315-322, 2005.

Harrison, R. G. and Carslaw, K. S.: Ion-aerosol-cloud processes in the lower atmosphere, Rev. Geophys., 41, 1012, doi:10.1029/2002rg000114, 2003.

Heiden, A. C., Hoffmann, T., Kahl, J., Kley, D., Klockow, D. Langebartels, C., Mehlhorn, H., Sandermann, H., Schraudner, M., Schuh, G., and Wildt, J.: Emission of volatile organic compounds from ozone-exposed plants, Ecol. Appl., 9, 1160-1167, 1999.

Hoffmann, T., Bandur, R., Marggraf, U., and Linscheid, M.: Molecular composition of organic aerosols formed in the alphapinene $/ \mathrm{O}_{3}$ reaction: Implications for new particle formation processes, J. Geophys. Res., 103, 25569-25578, 1998.

Holzinger, R., Lee, A., Paw, K. T., and Goldstein, A. H.: Observations of oxidation products above a forest imply biogenic emissions of very reactive compounds, Atmos. Chem. Phys., 5, 6775, doi:10.5194/acp-5-67-2005, 2005.

Inuma, Y., Boge, O., Gnauk, T., and Herrmann, H.: Aerosolchamber study of the alpha-pinene $/ \mathrm{O}_{3}$ reaction: Influence of particle acidity on aerosol yields and products, Atmos. Environ., 38, 761-773, doi:10.1016/j.atmosenv.2003.10.015, 2004.

Jenkin, M. E., Saunders, S. M., and Pilling, M. J.: The troposphericdegradation of volatile organic compounds: a protocol for 
mechanismdevelopment, Atmos. Environ., 31, 81-104, 1997.

Junninen, H., Hulkkonen, M., Riipinen, I., Nieminen, T., Hirsikko, A., Suni, T., Boy, M., Lee, S. H., Vana, M., Tammet, H., Kerminen, V. M., and Kulmala, M.: Observations on nocturnal growth of atmospheric clusters, Tellus B, 60, 365-371, doi:10.1111/j.1600-0889.2008.00356.x, 2008.

Junninen, H., Ehn, M., Petäjä, T., Luosujärvi, L., Kotiaho, T., Kostiainen, R., Roghner, U., Gonin, M., Fuhrer, K., Kulmala, M., and Worsnop, D. R.: A high-resolution mass spectrometer to measure atmospheric ion composition, Atmos. Meas. Tech., 3, 10391053, doi:10.5194/amt-3-1039-2010, 2010.

Kanakidou, M., Seinfeld, J. H., Pandis, S. N., Barnes, I., Dentener, F. J., Facchini, M. C., Van Dingenen, R., Ervens, B., Nenes, A., Nielsen, C. J., Swietlicki, E., Putaud, J. P., Balkanski, Y., Fuzzi, S., Horth, J., Moortgat, G. K., Winterhalter, R., Myhre, C. E. L., Tsigaridis, K., Vignati, E., Stephanou, E. G., and Wilson, J.: Organic aerosol and global climate modelling: A review, Atmos. Chem. Phys., 5, 1053-1123, doi:10.5194/acp-5-1053-2005, 2005.

Kirkby, J., Curtius, J., Almeida, J., Dunne, E., Duplissy, J., Ehrhart, S., Franchin, A., Gagne, S., Ickes, L., Kurten, A., Kupc, A., Metzger, A., Riccobono, F., Rondo, L., Schobesberger, S., Tsagkogeorgas, G., Wimmer, D., Amorim, A., Bianchi, F., Breitenlechner, M., David, A., Dommen, J., Downard, A., Ehn, M., Flagan, R. C., Haider, S., Hansel, A., Hauser, D., Jud, W., Junninen, H., Kreissl, F., Kvashin, A., Laaksonen, A., Lehtipalo, K., Lima, J., Lovejoy, E. R., Makhmutov, V., Mathot, S., Mikkila, J., Minginette, P., Mogo, S., Nieminen, T., Onnela, A., Pereira, P., Petaja, T., Schnitzhofer, R., Seinfeld, J. H., Sipila, M., Stozhkov, Y., Stratmann, F., Tome, A., Vanhanen, J., Viisanen, Y., Vrtala, A., Wagner, P. E., Walther, H., Weingartner, E., Wex, H., Winkler, P. M., Carslaw, K. S., Worsnop, D. R., Baltensperger, U., and Kulmala, M.: Role of sulphuric acid, ammonia and galactic cosmic rays in atmospheric aerosol nucleation, Nature, 476, 429-477, 2011.

Kroll, J. H. and Seinfeld, J. H.: Chemistry of secondary organic aerosol: Formation and evolution of low-volatility organics in the atmosphere, Atmos. Environ., 42, 3593-3624, doi:10.1016/j.atmosenv.2008.01.003, 2008.

Kulmala, M., Hämeri, K., Aalto, P., Mäkelä, J., Pirjola, L., Nilsson, E. D., Buzorius, G., Rannik, Ü., Dal Maso, M., Seidl, W., Hoffmann, T., Jansson, R., Hansson, H.-C., O`Dowd, C., and Viisanen, Y.: Overview of the international project on biogenic aerosol formation in the boreal forest (BIOFOR), Tellus B, 53, 324-343, 2001.

Kulmala, M., Riipinen, I., Nieminen, T., Hulkkonen, M., Sogacheva, L., Manninen, H. E., Paasonen, P., Petaja, T., Dal Maso, M., Aalto, P. P., Viljanen, A., Usoskin, I., Vainio, R., Mirme, S., Mirme, A., Minikin, A., Petzold, A., Horrak, U., Plass-Dulmer, C., Birmili, W., and Kerminen, V. M.: Atmospheric data over a solar cycle: No connection between galactic cosmic rays and new particle formation, Atmos. Chem. Phys., 10, 1885-1898, doi:10.5194/acp-10-1885-2010, 2010.

Laakso, L., Petäjä, T., Lehtinen, K. E. J., Kulmala, M., Paatero, J., Horrak, U., Tammet, H., and Joutsensaari, J.: Ion production rate in a boreal forest based on ion, particle and radiation measurements, Atmos. Chem. Phys., 4, 1933-1943, doi:10.5194/acp-41933-2004, 2004.

Lehtipalo, K., Sipila, M., Junninen, H., Ehn, M., Berndt, T., Kajos, M. K., Worsnop, D. R., Petaja, T., and Kulmala, M.: Observations of nano-CN in the nocturnal boreal forest, Aerosol Sci. Technol., 45, 499-509, doi:10.1080/02786826.2010.547537, 2011.

Lim, Y. B., Tan, Y., Perri, M. J., Seitzinger, S. P., and Turpin, B. J.: Aqueous chemistry and its role in secondary organic aerosol (SOA) formation, Atmos. Chem. Phys., 10, 1052110539, doi:10.5194/acp-10-10521-2010, 2010.

Mentel, T. F., Wildt, J., Kiendler-Scharr, A., Kleist, E., Tillmann, R., Dal Maso, M., Fisseha, R., Hohaus, T., Spahn, H., Uerlings, R., Wegener, R., Griffiths, P. T., Dinar, E., Rudich, Y., and Wahner, A.: Photochemical production of aerosols from real plant emissions, Atmos. Chem. Phys., 9, 4387-4406, doi:10.5194/acp9-4387-2009, 2009.

Metzger, A., Verheggen, B., Dommen, J., Duplissy, J., Prevot, A. S. H., Weingartner, E., Riipinen, I., Kulmala, M., Spracklen, D. V., Carslaw, K. S., and Baltensperger, U.: Evidence for the role of organics in aerosol particle formation under atmospheric conditions, P. Natl. Acad. Sci., 107, 6646-6651, doi:10.1073/pnas.0911330107, 2010.

Paasonen, P., Nieminen, T., Asmi, E., Manninen, H. E., Petaja, T., Plass-Dulmer, C., Flentje, H., Birmili, W., Wiedensohler, A., Horrak, U., Metzger, A., Hamed, A., Laaksonen, A., Facchini, M. C., Kerminen, V. M., and Kulmala, M.: On the roles of sulphuric acid and low-volatility organic vapours in the initial steps of atmospheric new particle formation, Atmos. Chem. Phys., 10, 11223-11242, doi:10.5194/acp-10-11223-2010, 2010.

Petäjä, T., Mauldin, R. L., Kosciuch, E., McGrath, J., Nieminen, T., Paasonen, P., Boy, M., Adamov, A., Kotiaho, T., and Kulmala, M.: Sulfuric acid and $\mathrm{OH}$ concentrations in a boreal forest site, Atmos. Chem. Phys., 9, 7435-7448, doi:10.5194/acp-97435-2009, 2009.

Plath, K. L., Axson, J. L., Nelson, G. C., Takahashi, K., Skodje, R. T., and Vaida, V.: Gas-phase vibrational spectra of glyoxylic acid and its gem diol monohydrate. Implications for atmospheric chemistry, React. Kinet. Catal. Lett., 96, 209-224, doi:10.1007/s11144-009-5528-2, 2009.

Reinnig, M-C., Warnke, J., and Hoffmann, T.: Identification of organic hydroperoxides and hydroperoxy acids in secondary organic aerosol formed during the ozonolysis of different monoterpenes and sesquiterpenes by on-line analysis using atmospheric pressure chemical ionization ion trap mass spectrometry. Rapid Commun. Mass Spectrom., 23, 1735-1741, doi:10.1002/rcm.4065, 2009.

Riipinen, I., Sihto, S. L., Kulmala, M., Arnold, F., Dal Maso, M., Birmili, W., Saarnio, K., Teinila, K., Kerminen, V. M., Laaksonen, A., and Lehtinen, K. E. J.: Connections between atmospheric sulphuric acid and new particle formation during QUEST III-IV campaigns in Heidelberg and Hyytiälä, Atmos. Chem. Phys., 7, 1899-1914, doi:10.5194/acp-7-1899-2007, 2007.

Saunders, S. M., Jenkin, M. E., Derwent, R. G., and Pilling, M. J.: Protocol for the development of the Master Chemical Mechanism, MCM v3 (Part A): tropospheric degradation of nonaromatic volatile organic compounds, Atmos. Chem. Phys., 3, 161-180, doi:10.5194/acp-3-161-2003, 2003.

Sipilä, M., Lehtipalo, K., Kulmala, M., Petäjä, T., Junninen, H., Aalto, P. P., Manninen, H. E., Kyrö, E. M., Asmi, E., Riipinen, I., Curtius, J., Kurtén, A., Borrmann, S., and O’Dowd, C. D.: Applicability of condensation particle counters to measure atmospheric clusters, Atmos. Chem. Phys., 8, 4049-4060, doi:10.5194/acp-8-4049-2008, 2008. 
Sipilä, M., Berndt, T., Petäjä, T., Brus, D., Vanhanen, J., Stratmann, F., Patokoski, J., Mauldin, R. L., Hyvärinen, A. P., Lihavainen, H., and Kulmala, M.: The role of sulfuric acid in atmospheric nucleation, Science, 327, 1243-1246, doi:10.1126/science.1180315, 2010.

Viggiano, A. A., Perry, R. A., Albritton, D. L., Ferguson, E. E., and Fehsenfeld, F. C.: Stratospheric negative-ion reaction-rates with $\mathrm{H}_{2} \mathrm{SO}_{4}$, J. Geophys. Res., 87, 7340-7342, 1982.

Wang, L., Khalizov, A. F., Zheng, J., Xu, W., Ma, Y., Lal, V., and Zhang, R. Y.: Atmospheric nanoparticles formed from heterogeneous reactions of organics, Nat. Geosci., 3, 238-242, doi:10.1038/Ngeo778, 2010.

Warscheid, B. and Hoffmann, T.: Direct analysis of highly oxidised organic aerosol constituents by on-line ion trap mass spectrometry in the negative-ion mode, Rapid Commun. Mass Spectrom., 16, 496-504, doi:10.1002/Rcm.602, 2002.

Weber, R. J., Marti, J., McMurry, P. H., Eisele, F. L., Tanner, D. J., and Jefferson, A.: Measured atmospheric new particle formation rates: Implications for nucleation mechanisms, Chem. Eng. Comm, 151, 53-64, 1996.

Wehner, B., Petäjä, T., Boy, M., Engler, C., Birmili, W., Tuch, T., Wiedensohler, A., and Kulmala, M.: The contribution of sulfuric acid and non-volatile compounds on the growth of freshly formed atmospheric aerosols, Geophys. Res. Lett., 32, L17810, doi:10.1029/2005g1023827, 2005.
Yasmeen, F., Vermeylen, R., Szmigielski, R., Inuma, Y., Boge, O., Herrmann, H., Maenhaut, W., and Claeys, M.: Terpenylic acid and related compounds: Precursors for dimers in secondary organic aerosol from the ozonolysis of alpha- and beta-pinene, Atmos. Chem. Phys., 10, 9383-9392, doi:10.5194/acp-10-93832010, 2010.

Yu, F. and Turco, R. P.: The size-dependent charge fraction of sub-3$\mathrm{nm}$ particles as a key diagnostic of competitive nucleation mechanisms under atmospheric conditions, Atmos. Chem. Phys., 11, 9451-9463, doi:10.5194/acp-11-9451-2011, 2011.

Zhang, Q., Jimenez, J. L., Canagaratna, M. R., Allan, J. D., Coe, H., Ulbrich, I., Alfarra, M. R., Takami, A., Middlebrook, A. M., Sun, Y. L., Dzepina, K., Dunlea, E., Docherty, K., DeCarlo, P. F., Salcedo, D., Onasch, T., Jayne, J. T., Miyoshi, T., Shimono, A., Hatakeyama, S., Takegawa, N., Kondo, Y., Schneider, J., Drewnick, F., Borrmann, S., Weimer, S., Demerjian, K., Williams, P., Bower, K., Bahreini, R., Cottrell, L., Griffin, R. J., Rautiainen, J., Sun, J. Y., Zhang, Y. M., and Worsnop, D. R.: Ubiquity and dominance of oxygenated species in organic aerosols in anthropogenically-influenced northern hemisphere midlatitudes, Geophys. Res. Lett., 34, L13801, doi:10.1029/2007g1029979, 2007. 